\title{
QUEEN'S
UNIVERSITY
BELFAST
}

\section{Assessing the effects of tidal stream marine renewable energy on seabirds: A conceptual framework}

Isaksson, N., Masden, E. A., Williamson, B. J., Costagliola-Ray, M. M., Slingsby, J., Houghton, J. D. R., \& Wilson, J. (2020). Assessing the effects of tidal stream marine renewable energy on seabirds: A conceptual framework. Marine Pollution Bulletin, 157, [111314]. https://doi.org/10.1016/j.marpolbul.2020.111314

Published in:

Marine Pollution Bulletin

Document Version:

Peer reviewed version

Queen's University Belfast - Research Portal:

Link to publication record in Queen's University Belfast Research Portal

Publisher rights

Copyright 2020 Ltd

This manuscript is distributed under a Creative Commons Attribution-NonCommercial-NoDerivs License

(https://creativecommons.org/licenses/by-nc-nd/4.0/), which permits distribution and reproduction for non-commercial purposes, provided the author and source are cited.

\section{General rights}

Copyright for the publications made accessible via the Queen's University Belfast Research Portal is retained by the author(s) and / or other copyright owners and it is a condition of accessing these publications that users recognise and abide by the legal requirements associated with these rights.

Take down policy

The Research Portal is Queen's institutional repository that provides access to Queen's research output. Every effort has been made to ensure that content in the Research Portal does not infringe any person's rights, or applicable UK laws. If you discover content in the Research Portal that you believe breaches copyright or violates any law, please contact openaccess@qub.ac.uk. 
Title: Assessing the effects of tidal stream marine renewable energy on seabirds: a conceptual framework

Authors: Natalie Isaksson ${ }^{a}$, Elizabeth Masdenª, Benjamin Williamsonª, Melissa Costagliola-Raya, James Slingsby ${ }^{a}$, Jonathan Houghton ${ }^{\mathrm{b}}$, and Jared Wilson ${ }^{\mathrm{c}}$

Corresponding author: Natalie Isaksson

\section{Affiliations:}

a Environmental Research Institute, North Highland College, University of the Highlands and Islands, Ormlie Road, Thurso KW14 7EE, UK

${ }^{\text {b }}$ School of Biological Sciences, Queen's University Belfast, Belfast BT9 7BL, Northern Ireland, UK

c Marine Scotland Science, Marine Laboratory, 375 Victoria Road, Aberdeen, AB11 9DB

Keywords: collision risk, displacement, habitat use, environmental impact assessment, monitoring, tidal energy device

\section{Abstract}

We are at a crossroads where many nation states, including the United Kingdom of Great Britain and Northern Ireland (UK), are committing to increased electricity production from "green energy", of which tidal stream marine renewable energy is one such resource. However, many questions remain regarding the effects of tidal energy devices on marine wildlife, including seabirds, of which the UK has internationally important numbers. Guidelines are lacking on how best to use both wellestablished and novel survey methods to assess seabird use of tidal flow areas, leading to a data-rich but information poor (DRIP) situation. This review provides a conceptual framework for assessing the effects of tidal stream energy devices on seabirds, summarises current knowledge and highlights knowledge gaps. Finally, recommendations are given for how best to pursue knowledge on this topic.

\section{An overview of the tidal stream marine renewable energy seascape and seabirds}

The Intergovernmental Panel on Climate Change (IPCC) has called for a 'massive shift' toward renewable energy in light of determining unequivocal climate warming as a result of anthropogenic activity (Edenhofer et al., 2011; Intergovernmental Panel on Climate Change, 2014). Consequently,

Commented [NI1]: R2: "to best pursue knowledge on this thematic"

Commented [NI2R1]: I feel 'thematic' Is a bit vague so put topic instead but open to suggestions. 
targets for electricity production from renewable sources have been set by governing bodies: ‘ $80 \%$ by 2050, worldwide'; '20\% by 2020, EU' (European Commission's Renewable Energy Directive, 2009/28/EC:EC2009a); 'net zero by 2045 Scotland' (Climate Change Act, 2019). Renewable energy from offshore wind, wave and tidal, herein referred to as marine renewables, have the theoretical potential to supply up to 7\% of worldwide electricity demand (Fujita, 2002; Resch et al., 2008; Esteban and Leary, 2012; Pelc and Shields and Payne, 2014). Tidal energy alone is estimated to have the potential to deliver ca. " $20 \%$ of the UK's current electricity needs" with an ultimate average capacity of 40GW (Melikoglu, 2018).

The fundamental driving mechanisms of tidal currents allow for a predictable resource that can be reliably utilised (Wolanski \& Hamner 1988; Bryden and Melville 2004; O'Rourke, Boyle, and Reynolds 2010). However, in order for tidal stream marine renewable energy devices (hereafter tidal energy devices) to be commercially viable, mean spring tide current velocities $>2 \mathrm{~ms}^{-1}$ are necessary (Fraenkel, 2006; Lewis et al., 2015). Several tidal stream environments around the world where such velocities occur regularly have been explored for tidal energy development, most notably in Canada, China, France, the UK, and the US (Ocean Energy Systems 2016; Zhou et al. 2017; Marine Renewables Canada 2018). The UK, in particular, holds ca. 50\% of Europe's tidal energy resource, and is home to 31 tidal development sites including the European Marine Energy Centre (EMEC), which has been at the forefront of tidal energy development (Shields et al. 2009; Magagna and Uihlein 2015; Neill et al. 2017; Marine Energy Council 2019; www.thecrownestate.co.uk). The challenges of tidal stream environments, not least the greater density of water compared to air, have resulted in a wide variety of tidal energy device designs (Bryden et al. 2004, Fraenkel 2004). While the gravity-base mounted horizontal-axis turbine is the most common design, accounting for over $70 \%$ of global research and development effort, more unique adaptations including floating turbines and tidal kites are being trialled (Fox et al., 2018; Segura et al., 2018).

Tidal stream environments are not only important from a renewable energy perspective. These dynamic environments are used for foraging, transport and/or breeding opportunities across a 
range of fauna including fish (e.g. Atlantic herring Clupea harengus (Lacoste et al., 2001)), invertebrates (e.g. velvet crab Necora puber (Broadhurst and Orme, 2014)), marine mammals (e.g harbour seal Phoca vitulina (Van Parijs et al., 1999)) and seabirds. Aside from Magellanic penguins Spheniscus magellanicus in Tierra del Fuego, Argentina, which use tidal streams to minimize energetic Commented [NI3]: R2: "that of use" to "which" costs of transit to foraging sites, seabirds mainly use these environments for foraging (Raya Rey et al. 2010; Furness et al. 2012), thereby providing a context for their potential interactions with tidal energy devices. The UK, and Scotland in particular, has internationally important seabird populations, of which many are designated under the EU Habitats Directive (92/43/EEC) and EU Birds Directive (2009/147/EEC (BD)) (Mitchell et al., 2004; European Commission, 2013). As such the UK has a legal responsibility to conserve its seabird populations. However, seabird breeding numbers in the UK have decreased by $9 \%$ since 2000 , most notably in species that forage on small fish species such as sand eels (Ammodytes sp) (JNCC, 2007) due to over-fishing and rising sea temperature, as well as predation of seabirds by invasive mammals, especially American mink Neovison vison (Frederiksen et al. 2004; Wanless et al. 2007; Langston 2010). In the face of these challenges, additional pressure from tidal energy developments, especially those near major seabird breeding colonies, is of concern (Copping et al. 2016; Dias et al. 2019; Figure 1).

The main potential effects of tidal energy devices on seabirds are mortality (or injury) caused by underwater collision with turbine blades and displacement as a result of habitat loss due to habitat and/or prey behaviour modification, disturbance (i.e. increased vessel traffic associated with installation, maintenance, decommissioning), and barrier effects (i.e. energetic costs of avoiding turbines) (Wilson et al. 2006; Inger et al. 2009; Langton, Davies, and Scott 2011; Furness et al. 2012; Scott et al. 2014; Copping et al. 2016; Fox et al. 2018; ICES 2019). Regarding anthropogenic disturbance to natural systems, it is important to clarify and distinguish between terms that are often used interchangeably: 'effects' and 'impacts'. Effects are changes of environmental features by a stressor (e.g. tidal energy device) on a receptor (e.g. individual seabird), that fall outside the range of natura variability. Impacts relate to the intensity and duration of an effect on a receptor such as seabird 
populations. Before there can be negative impact from marine renewables, the effect must be shown to be significant or large enough to cause change at the population level (Boehlert and Gill, 2010). Empirical evidence for the effects and impacts of tidal energy devices on seabirds is lacking, as are guidelines on efficient use of survey methods to fill these knowledge gaps (Furness et al. 2012; Kirby et al. 2013; Benjamins et al. 2015; Bonar, Bryden, and Borthwick 2015; Copping et al. 2016; ICES 2019). The following review therefore 1) presents a conceptual framework to guide the choice of method for assessing potential effects, 2) summarises current knowledge and knowledge gaps, and 3) recommends how best to advance the state of the science. Due to the number of seabird monitoring studies conducted at tidal energy development sites in the UK (Table 1), the following review has a UK-centric perspective; the applicability, however, is global.

\section{A conceptual framework to guide the selection of methods to assess potential effects of} tidal energy devices on seabirds

In order to assess impacts of tidal energy devices to seabirds from collision and displacement, the modelling approaches used in risk assessments of offshore wind turbines have been adapted (Scottish Natural Heritage, 2016; Searle et al., 2018). However, the outputs of any model depend on the inputs and prior to impacts, effects must be measured. There is a need for guidelines on how best to use available and novel methods (described in Appendix 1, Figure 3) to quantify effects from tidal energy devices on seabirds (Copping et al. 2016; Roche et al. 2016; ICES Special Request Advice 2019). Collision risk and displacement are inherently multi-dimensional and complex effects (Fox et al., 2018); breaking these down into more manageable and measurable components for the purpose of identifying knowledge gaps and the methods by which to fill them is merited (Figure 2, Figure 3). Depending on additional considerations such as logistics and expense, the most appropriate method or set of methods can then be selected for monitoring of the effect of interest from tidal energy devices (Table 2). 


\subsection{Collision risk}

Underwater collision with moving parts of tidal energy devices resulting in injury or death is considered to be the major risk for seabirds (Furness et al. 2012; McCluskie, Langston, and Wilkinson 2013; Copping et al. 2016). Mortality of individuals, in particular adults, has the potential to significantly impact population dynamics (Furness and Monaghan 1987; Sæther and Øyvind 2000; Furness et al. 2012). While no collision between a tidal device and a seabird has been observed directly (Copping et al., 2016), it is a very real concern for consenting bodies and the general public. Collision here is defined as the physical interaction between a seabird and moving parts of a tidal energy device that results in injury or mortality (adapted from Wilson et al. 2007). Collision between dynamic components (e.g. rotating blade) of the device is of greatest concern although collision with static components is a possibility (Scottish Natural Heritage, 2016; Long, 2017). Whether collision with moving components occurs will depend on spatial, temporal and behavioural factors, all of which must be satisfied for there to be risk (Figure 2). These are, in order: 1) spatial overlap in horizontal and vertical dimensions, 2) temporal overlap, and 3) lack of evasion.

Spatial overlap can be broken down into relevant monitoring scales: habitat (the tidal stream environment, 1-10km), micro-habitat (within the tidal stream environment, $<1 \mathrm{~km}$ ) and close-range $(<100 \mathrm{~m})$. Building on Waggitt and Scott (2014), the use of a tidal stream environment must first be determined at the habitat scale $(1-10 \mathrm{~km}$, Figure 2). Once tidal stream environment association is established, the use of areas suitable for tidal energy device deployment, that is in areas with fast horizontal current speeds and hard-smooth seabeds (Fraenkel 2006; micro-habitat, Figure 2) must be quantified. As tidal turbines operate at specific depths in the water column (approx. 10-40m, Langton et al. 2011), there is a vertical component of overlap that needs to be assessed as well (Waggitt and Scott 2014, $\Delta$ d in Figure 2). Within micro-habitats suitable for tidal energy devices, collision will furthermore depend on close-range overlap with the area of rotating blades underwater $(<100 \mathrm{~m}, \Delta \mathrm{h}$ in Figure 2). Collision risk can also be expected to be minimal if seabirds do not make use of tida stream environments at times when devices are operational (i.e. at peak flow times). Determining 
whether seabirds use tidal stream environments at specific tidal phases (e.g. ebb/flood, slack) throughout the annual cycle is therefore necessary. Close-range behaviour (e.g. evasion) by a seabird in the 'collision risk zone' $(\Delta \mathrm{h} \times \Delta \mathrm{d}$, Figure 2), will ultimately determine whether collision occurs (Copping et al., 2016). Evasion will depend on small-scale foraging behaviour, visual or other sensory acuity, swim speeds and agility. While effects of devices no matter design are presumed to be similar at broader scales (Fox et al., 2018) it is conceivable that at the small (i.e. seconds, minutes, metres) spatio-temporal scales at which evasion would occur that device design will also play a role.

\subsection{Displacement effects}

Displacement is the redistribution of individuals from an area as a consequence of changes in habitat or prey availability, disturbance, or sometimes barrier effects (Long 2017; Jarrett et al. 2018 Figure 2). As is the case with collision risk, seabirds can only be displaced if they already use the tida stream environment (habitat-scale, $>1 \mathrm{~km}$, Figure 2). After establishing that seabirds use the habitat, micro-habitat use $(<1 \mathrm{~km})$ within the tidal stream environment, including foraging behaviour and any underlying factors (e.g. habitat characteristics, prey), can be assessed. Finally, sensitivity to disturbance and the extent to which individuals are risk-averse and therefore likely to perceive the turbines as barriers will also influence the likelihood of displacement.

Functional habitat loss by way of altered prey behaviour or availability has been identified as a potential effect of tidal energy devices (Benjamins et al. 2015; Copping et al. 2016; Fox et al. 2018). As underwater tidal devices extract kinetic energy, this will likely lead to hydrodynamic modification, that is, changes in water movement and turbulence (O'Doherty et al. 2010; Shields et al. 2011; Stallard et al. 2013; Haverson et al. 2018). Benthic habitats and ecosystems within tidal stream environments are most likely to be affected by changes in water circulation, currents, and the structure of the habitat itself as they are adapted to strong currents (Gómez-Gutiérrez and Robinson 2006; Neill et al. 2009; Boehlert and Gill 2010; Miller et al. 2013; Robins, Neill, and Lewis 2014; Bicknell et al. 2019; Dannheim et al. 2019). Species composition, including fish prey, could be altered as a consequence of hydrographic modification with consequences for benthic foraging seabirds, such as black guillemots 
Cepphus grylle and European shags Phalacrocorax aristotelis, especially (Furness et al. 2012; Miller et al. 2013). This process in turn could lead to population level impacts depending on the proportion of tidal stream environment foraging specialist individuals and their respective sex ratio (Irons, 1998). The magnitude and persistence of disturbance is likely to influence whether seabirds temporarily avoid an area or are permanently displaced (Jarrett et al., 2018). Seabirds may be disturbed by increased vessel traffic associated with deployment, maintenance and decommissioning of devices as well as by underwater noise associated with deployment and operation of devices (Fox et al., 2018; Frid et al., 2012). Previous studies have mainly discussed barrier effects and avoidance in the context of offshore windfarms and seabirds commuting to foraging patches (Desholm and Kahlert, 2005; Masden et al., 2009; Cook et al., 2014). Additional energetic costs imposed by taking a detour around the turbines are the main concern and will largely be influenced by the personality of the seabird (e.g. risk-averse or not).

\section{Current knowledge and knowledge gaps}

\subsection{Collision risk}

\subsubsection{Spatial overlap}

Desk-based studies assessing the potential vulnerability of UK seabirds to tidal energy devices have identified (in decreasing order) razorbill Alca torda, European shag, black guillemot, common guillemot Uria aalge, and great cormorant Phalacrocorax carbo as particularly vulnerable due to their use of tidal races for subsurface foraging (Furness et al. 2012; Wade et al. 2016; references therein). In addition, empirical studies have explicitly assessed seabird use of tidal stream environments at the habitat scale (Figure 2, Table 1). These studies have used a variety of survey methods (reviewed in Appendix 1), most commonly land-based vantage point and boat-based surveys that give a general picture of habitat use (Table 1, Figure 3). These studies show that in addition to those already mentioned, several species of auks (e.g. Atlantic puffin Fratercula arctica (Waggitt et al., 2014, 2016a), gulls (e.g. black-legged kittiwake Rissa tridactyla (Embling et al. 2012; Drew, Piatt, and Hill 2013), and terns (e.g. Arctic tern Sterna paradisaea (Savidge et al. 2014; Lieber et al. 2019) use tidal stream 
environments (Table 1). Conversely, sea ducks (e.g. common eider Somateria mollissima) and divers (e.g. great northern diver Gavia immer) avoid areas of strong tidal currents (Holm and Burger 2002; Heath and Gilchrist 2010).

Questions remain at the habitat scale, however. Northern fulmar Fulmaris glacialis and sooty shearwater Ardenna grisea are examples of seabird species for which the extent of use of tidal races is not completely clear (for full list see Wade et al. 2016). As land-based survey methodologies often used to assess habitat-scale use $(>1 \mathrm{~km})$ are not standardised (Waggitt, Bell, and Scott 2014; Waggitt et al. 2017), comparison between sites is difficult which impedes the ability of make generalisations. Furthermore, many surveys have been conducted at the same few sites (e.g. Fall of Warness, Pentland Firth, Bay of Fundy; inset Figure 1, Table 1) and seabird foraging behaviour is often site-specific (Fauchald, 2009). Evidence from a more diverse range of tidal stream environments and species, collected in a standardised manner, would help to identify generalities in use of tidal stream environments, especially with regard to potential expansion of tidal energy development sites worldwide.

Within tidal stream environments (micro-habitat $<1 \mathrm{~km}$, Figure 2 ), spatial overlap appears to be site-, species-, and even study-specific. A study seeking to generalize seabird site-use across Scotland found that black guillemots were more often detected in fast-flowing microhabitats (Waggitt et al. 2017; Table 1). On the other hand, at Bluemull Sound (Shetland, Scotland, Figure 1), decreasing numbers of black guillemots at increasing current speeds was found (Robbins 2017; Table 1), while the opposite was found in an earlier study at the site (Rodger 2014; Table 1). However, in the Bay of Fundy, Canada, black guillemots avoid both extremes of current speeds, associating instead with areas of moderate current flow (Nol and Gaskin, 1987). Notably, studies conducted in North America suggest that seabirds partition tidal stream environments by foraging behaviour (Hunt et al. 1998; Drew, Piatt, and Hill 2013; Table 1). Site- and species-specificity appears to also hold true also in terms of spatial overlap with tidal lease sites (Figure 1). For instance, GPS tracking of great skua Stercorarius skua and black guillemots breeding adjacent to or within the Inner Sound (Scotland, UK, inset Figure 1), found 
no overlap with the tidal lease site therein (Table 1, (Wade et al. 2014; Johnston 2019). However, breeding terns at Strangford Lough, Northern Ireland, foraged predominantly in conjunction with the wake of the SeaGen turbine (Lieber et al., 2019).

Associations between areas of fast tidal flow and the extent to which this is site and/or species specific remains to be quantified. The physical properties of the particular tidal stream environment, as well as foraging behaviour (e.g. pursuit-diver or not) and potentially even presence of other seabird species competing for resources (Hunt Jr et al., 1998; Drew et al., 2013) may all be important in determining how seabirds use the habitat. Facilitative interactions between marine mammals and seabirds may also play a role (Goyert et al., 2018). Greater understanding of the particular conditions underlying the use of high tidal flow areas (i.e. habitat, hydrodynamics, prey assemblages) will also allow for predictions of site-use to be made at sites for which data are lacking (Waggitt and Scott 2014). Studies disentangling these relationships and quantifying multiple explanatory variables behind seabird habitat use are therefore needed. This is a complex undertaking and therefore breaking down the effect(s) of interest into manageable units via a conceptual framework (Figure 2) is one strategy.

While assessing horizontal spatial overlap with tidal energy devices is important, there is no underwater collision risk without vertical spatial overlap (i.e. depth, $\Delta d$ in Figure 2). Desk-based studies collating mean and maximum depths of seabirds in the UK have identified razorbill, European shag, black guillemot, common guillemot and great cormorant as seabirds that dive to 'collision risk zone' depths (Langton, Davies, and Scott 2011; Furness et al. 2012; Wade et al. 2016; Robbins 2017; MMO 2019; $\Delta \mathrm{d}$ in Figure 2). One study on diving depths of black guillemots in the Inner Sound, UK (Figure 1) determined that individuals dived to $32 \mathrm{~m}$ on average, which is within a depth range where tidal rotors could be operational (10-40m below sea level, Langton et al., 2011; Masden et al., 2013; Table 1). Furthermore, $62 \%$ of dives were in water deep enough for a tidal device and $37 \%$ of dive time was spent in depths where tidal rotors could be operational (Masden et al., 2013). On the other hand, a study at the Fall of Warness (Figure 1) did not find an association between water elevation and abundance of black guillemot or European shag (Waggitt et al. 2016b). It is worth noting here that 
dive depth data devoid of the context of the bathymetry of the area can be misleading. For instance, if a bird does not dive to turbine depths, this is only relevant if the seafloor is far enough below to have contained a turbine. The relationship between the number of dives to certain depths and bathymetry at tidal lease sites has yet to be satisfactorily explored. Also, empirical data on vulnerable seabird species' dive depths within tidal stream environments is lacking. Finally, dive depths need to be assessed with regards to hitherto less common but increasingly popular device designs (e.g. tidal kite, floating turbine) with spatial footprints potentially larger than seafloor-mounted horizontal axis turbines.

The final and arguably most difficult piece of the spatial overlap puzzle is that of close-range overlap ( $<100 \mathrm{~m}, \Delta \mathrm{h}$ in Figure 2 ). One study so far has used an integrated instrumentation package of active acoustic sensors at the Fall of Warness EMEC test site to record dives performed by seabirds near the seabed-mounted gravity base of a turbine (Williamson et al. 2017). Sample images from underwater video monitoring data from monitoring cameras deployed on tidal turbines appear to indicate that schooling fish avoid turbine blades by moving towards the base of the turbine when operational, although whether this affects seabird collision is unknown (Hutchison et al., 2019). Whether seabirds forage in the vicinity but successfully evade turbines $(<100 \mathrm{~m})$ is currently entirely unknown (Wilson et al. 2007; Copping et al. 2016). As such there is a need to quantify collision and collision mortality by e.g. underwater monitoring of turbines to detect collisions and/or avoidance behaviour.

\subsubsection{Temporal overlap}

Broadly, seabirds are known to exhibit tidal phase affinity, that is, foraging at specific sites during certain phases of the tide (Becker, Frank, and Sudmann 1993; Irons 1998; Embling et al. 2012; Trevail et al. 2019;). It is hypothesized that this is due to enhanced prey availability due to thermal stratification and advection by associated hydrodynamics (e.g. current speed, turbulence) (Fraser et al. 2018; B. Williamson et al. 2019). This is known as the 'tidal coupling hypothesis' (Wolanski and Hamner 1988; Zamon 2003). 
Tidal phase affinity has been found for seabirds that use tidal stream environments at certain locations, the main predictor of which appears to be prevailing current speed associated with the particular tidal phase (Table 1). A pattern of temporal use depending on foraging behaviour is also beginning to emerge, whereby benthic foragers (e.g. black guillemot) associate with periods of slack tide (when horizontal current speeds are lowest) and more pelagic foragers (e.g. common guillemot) with periods of ebb and flood (when horizontal current speeds are fast). This is the case at the Fall of Warness (UK, inset Figure 1), where foraging black guillemot and European shag densities were greatest during slack tide while Atlantic puffin and common guillemot associated with times when horizontal current speeds were faster (Waggitt et al. 2016a; 2016b). On the other hand, great cormorants foraged most actively during flood tide at Ramsey Sound, UK (Cole et al., 2019) and at the Isle of May, UK, European shags associated with increasing and maximum flood (Philpott, 2013). Terns (surface feeders), have been shown to forage during periods of maximum flood, when turbulence is likely to bring prey items to the surface (Lieber et al., 2019). In North American tidal stream environments, most auks (e.g. pigeon guillemot, ancient-, marbled murrelet Brachyramphus marmoratus) and surface-feeders (e.g. gulls Laridae, terns Sternidae) have been found to associate with tidal phases with high current speeds, (Braune and Gaskin 1982; Hunt et al. 1998; Holm and Burger 2002; Zamon 2003; Ladd et al. 2005; Drew, Piatt, and Hill 2013; Urmy and Warren 2018). There is also evidence that any effects of tidal state on seabird abundance may be mediated by the time of day and internal state of the bird (e.g. breeding vs non-breeding) (Nol and Gaskin 1987; Waggitt et al. 2016b; Walker and Taylor 2018). However, some studies have found that tidal state is not a predictive variable for seabird presence, potentially due to the site-specific nature of prevailing hydrodynamics at work during different periods of the tidal cycle (Warwick-Evans et al. 2016; Waggitt et al. 2017; Goodman 2019). The inconsistencies between species at different sites highlight the need to identify prevailing hydrodynamics and prey behaviour during the different tidal states. A greater understanding of these underlying factors and how the magnitude of these might be mediated by 
local bathymetry and topography will go a long way in determining the extent of tidal phase affinity in tidal stream environments (Waggitt and Scott 2014).

Seasonal use of tidal stream environments will also influence collision risk, with resident and short distance migrants being more vulnerable as they remain in the area or very near. Many north Atlantic seabirds, including Atlantic puffins, common guillemots, razorbills, black-legged kittiwakes, and northern gannets Morus bassanus migrate further out to sea during the non-breeding season (Guilford et al. 2011; Frederiksen et al. 2012; Linnebjerg et al. 2013). European shags and black guillemots, on the other hand, are resident or perform only short migrations during the non-breeding season which potentially means more time spent in tidal stream environments and therefore greater risk of collision (Robbins, 2012; Grist et al., 2014). It is also possible that prey assemblages in tidal stream environments change throughout the season, and/or that, free from the constraints of centralplace foraging, birds may exploit a wider range of prey during the non-breeding season (Orians and Pearson 1979; Lessells and Stephens 1983; Weimerskirch 2007; Waggitt et al. 2016b). Periods of moult (when birds change plumage) during the non-breeding season are also likely to affect diving and flight performance, thereby potentially increasing sensitivity to stressors during this time (Nol and Gaskin, 1987).

Several studies have reported on the seasonal use of tidal stream environments by seabirds, especially in the UK and Canada (Table 1). European shag and black guillemot are observed year-round at most sites, while other seabird species (e.g. common guillemot, razorbill) are less abundant during winter months (Wade 2015; Robbins 2017; Taylor and Walker 2019). Notably, at the Fall of Warness (UK, Figure 1), black guillemot and European shag associated with a broader range of hydrodynamic and substrate characteristics during non-breeding than breeding (Waggitt et al. 2016b), thus potentially increasing vulnerability to tidal energy devices during winter. In order to get the full picture of seabird use of tidal stream environments it is therefore important to perform surveys throughout the annual cycle. Furthermore, studies need to not only quantify seabird presence but also behaviour, 
such that prevalence of seabird foraging at semi-diurnal and fortnightly tidal phase throughout the entire year can be determined.

\subsubsection{Evasion}

Close-range behaviour of seabirds around tidal energy devices and whether/how evasive action is taken is currently unknown (Wilson et al. 2006; Copping et al. 2016; Band 2016). 'Conveyor belt' foraging exhibited by several diving seabird species including black guillemot, pigeon guillemot, European shags and common eider (Nol and Gaskin 1987; Holm and Burger 2002; Heath and Gilchrist 2010; Robbins et al. 2014; Rodger 2014; Wade 2015) is predicted to reduce the ability of birds to detect devices as the devices will be approached 'backwards', i.e. facing away from the devices and into the current (Wade 2015). The prevalence of conveyor-belt foraging for birds diving to collision risk depths $(\Delta d$, Figure 1) within tidal lease sites has yet to be quantified. The extent to which tidal energy devices may act as fish aggregating devices that enhance foraging opportunities for seabirds while simultaneously potentially increasing collision risk is also unclear (Broadhurst et al., 2014; Fraser et al., 2018; Williamson et al., 2019; Whitton et al., 2020).

Detection will also be influenced by the shape, size and type of device (e.g. seabed-mounted horizontal axis turbine vs. tidal kite vs. floating devices), water turbidity, and the sensory capabilities of the seabird (Martin and Wanless, 2015; Fox et al., 2018). While vision is presumed to be the principal sense of prey detection and acquisition for seabirds, some species such as great cormorants have notoriously poor vision and could rely more on tactile cues, making it harder to detect devices in the water column (Katzir 2003; White et al. 2007; Martin, White, and Butler 2008; Johansen et al. 2016; Hansen et al. 2017). Based on measurements of visual field parameters, Atlantic puffins and common guillemots are predicted to have reduced visual fields underwater thus rendering them vulnerable to obstacles ahead of them such as turbines (Martin and Wanless, 2015). African penguins (Spheniscus demersus) have been shown to use acoustic signalling and avoid operational seismic survey vessels, presumably due to underwater noise pollution (Pichegru et al. 2017; Mclnnes et al. 
2019). Whether noise from tidal turbines could aid in detection and avoidance as it is speculated to do for birds avoiding wind farms (Inger et al., 2009) remains unknown.

The speed at which a device is approached will affect evasion ability, with higher speeds expected to impede evasive manoeuvring. While swim speeds for several seabird species have been deduced through accelerometery (Lovvorn 2004; Heath, Gilchrist, and Ydenberg 2006; RopertCoudert, Grémillet, and Kato 2006; Watanuki et al. 2006; Chimienti et al. 2016), speeds in tidal stream environments let alone tidal lease sites near turbines have yet to be determined. Finally, the agility and behaviour of seabirds around moving devices underwater is a major knowledge gap. From studies in air on collision risk in wind farms it has been found that seabirds vary in their evasion ability (Garthe and Hüppop, 2004; Bradbury et al., 2014;). It is not clear how this translates underwater.

\subsection{Displacement}

\subsubsection{Habitat and prey modification}

Optimal foraging theory dictates that predators such as seabirds should maximize their energy intake by concentrating foraging efforts in areas where prey are abundant, accessible and predictable (Weimerskirch 2007; Fauchald 2009). Tidal stream environments are predictable habitats that can concentrate and make prey accessible to seabirds via hydrodynamic mechanisms (e.g. current speed, turbulence) that in turn lead to exploitable features (e.g. boils, wakes) (Zamon 2001; Enders, Boisclair, and Roy 2003; Johnston, Westgate, and Read 2005; Gómez-Gutiérrez and Robinson 2006; Enstipp, Grémillet, and Jones 2007; Embling et al. 2012; Cox, Scott, and Camphuysen 2013). Hydrographic modification by the introduction, maintenance and decommissioning of tidal energy devices (including cables) in these environments could lead to changes in fish prey availability, with consequences for seabirds (Neill et al. 2009; Miller et al. 2013; Broadhurst and Orme 2014; Martin-Short et al. 2015; Taormina et al. 2018; Dannheim et al. 2019; Williamson et al. 2019). A few studies have established a link between hydrographics, seafloor biome, and seabird foraging in tidal stream environments (Table 1). For instance, seabed substrate has been found to be a predictor of European shag occurrence (Waggitt et al. 2016b; Warwick-Evans et al. 2016) and prevalence of kelp Laminaria hyperborea at 
shallow depths may predict black guillemot foraging locations (Johnston 2019). At Strangford Lough terns forage in wake features associated with the SeaGen tidal turbine structure, presumably as these bring prey to the surface (Lieber et al., 2019). Similarly, common tern Sterna hirundo and roseate tern Sterna dougallii have been shown to rely on fast tidal flow over shallow depths that make prey available at the sea surface (Urmy and Warren, 2018).

The need for studies ascertaining whether seabirds experience foraging habitat loss (via changes in prey behaviour) from the development of tidal energy devices, the scale at which this occurs and degree of habituation has been expressed previously (Fox et al., 2018; Jarrett et al., 2018). Studies investigating the extent to which tidal energy devices may increase prey availability by acting as fish aggregating devices and therefore ecological traps, are also merited (Broadhurst et al., 2014; Fraser et al., 2018; Williamson et al., 2019< Whitton et al., 2020). As there are currently few tidal energy arrays ( $>1$ turbine) deployed worldwide (but see the Pentland Firth, Figure 1 and Bluemull Sound, UK (https://www.renewableuk.com/page/WaveTidalEnergy)), the extent of habitat loss due to modification is difficult to measure. Identifying the underlying mechanism(s) which influence successful seabird foraging, including the prevalence of conveyor belt foraging and associations with particular hydrodynamic features in tidal stream environments may allow for the effect of any changes in hydrodynamics by tidal energy devices on seabirds to be predicted (Scott et al., 2014). This will necessitate combining methods that can assess both habitat-scale and fine-scale variables, including surface features such as boils or wakes.

\subsubsection{Disturbance}

Seabirds vary in their sensitivity to boat traffic and are expected to show a response to vessel activity associated with marine renewable energy device deployment, maintenance, and decommissioning (Furness et al. 2012). Studies on Orkney (Figure 1) indicate that black and common guillemot, divers, European shags and great cormorants are likely to flush (fly away) in response to vessel activity (Long, 2017; Jarrett et al., 2018). However, it is unknown to what extent this is sitespecific and whether habituation to regular vessel traffic occurs. Information on the sensitivity of a 
variety of seabird species to marine activity associated with tidal energy deployment, operation and decommissioning, from a range of sites is needed. As persistence of a disturbance events is important, seabirds that use tidal stream environments year-round (e.g. black guillemots, European shags) should be prioritized.

\subsubsection{Barrier effects}

Barrier effects are most likely to affect seabirds by increasing energetic costs associated with foraging, that is having to capture prey while simultaneously avoiding turbines. Monitoring at Strangford Lough (Figure 1) suggests that tidal energy devices placed near ( $50 \mathrm{~m})$ each other in an array could potentially be a barrier to movement for diving seabirds such as auks and cormorants (Savidge et al., 2014). However, this is an assessment based on a single device in a very narrow channel. Filling in the knowledge gaps on parameters influencing near-field collision risk (e.g detection) and individual behaviour (e.g. risk-averse or not) will help in beginning to understand how tidal energy devices might act as barriers.

\section{Recommendations for future research: addressing knowledge gaps}

Guidelines on best to select survey methods and use data generated by these to assess seabird use of tidal flow areas are currently lacking (Copping et al., 2016; ICES Special Request Advice, 2019). Information on how seabirds behave within tidal stream environments (micro-habitat, $<1 \mathrm{~km}$ ) and in the immediate vicinity of tidal energy devices (close-range, $<100 \mathrm{~m}$ ), above all, is needed. While many methods are available, there is no 'one method fits all', In addition to their inherent limitations, suitability will depend on the particular features and logistics of a given site, not to mention the knowledge gap(s) seeking to be addressed (Figure 2, Figure 3, Appendix 1). Appropriate monitoring methods (Appendix 1) to assess potential effects at relevant dimensions and scales are summarised in Table 2 and discussed below.

\subsection{Collision risk}

At least 30 studies have investigated seabird use of tidal stream environments at a habitat-wide scale ( $>1 \mathrm{~km}$, Table 1). The majority of these studies have been conducted in the UK and at a few sites 
therein, making predictions about habitat use of a range of seabird species on a global scale difficult (e.g. Fall of Warness, Inner Sound; inset Figure 1, Table 1). As most of the studies have used landbased vantage point surveys to quantify seabird presence and abundance and this method has yet to be standardised (Appendix 1), the difficulty of drawing generalisations from these data is further exacerbated. Standardising this method is therefore a priority (Waggitt and Scott 2014; Waggitt, Bell, and Scott 2014). In order to also be able to gather information on foraging behaviour, conducting focal watches from land may be a solution (Waggitt et al. 2017; Figure 3). Marine radar deployed from a high vantage point on shore overlooking and providing coverage of an entire site, is potentially effective as a trigger for other instruments as part of an integrated package, or as a complement to land-based surveys (Mateos et al. 2010; Polagye et al. 2014; McCann and Bell 2017; Walker and Taylor 2018; Appendix 1, Figure 3). Surveys conducted from a vessel or aerially are also suitable methods to assess abundance and presence at this scale, although logistics and cost are potentially prohibitive (Appendix 1, Figure 3). Where bird-borne telemetry data for seabirds breeding at nearby colonies already exist, the analysis of these should be prioritized as the precision and resolution lends itself to more fine-scale habitat-use assessment (Appendix 1, Table 2, Figure 3).

Within tidal stream environments $(<1 \mathrm{~km}$, Figure 2$)$, foraging behaviour and its underlying factors (e.g. benthos, depth, prey) and species-specific associations with fast tidal flow and predictable features (e.g. eddies, boils) need to be quantified (Scott et al. 2014; Waggitt, Bell, and Scott 2014; Warwick-Evans et al. 2016) . Land-based focal watches of behaviour within fast-flowing micro-habitats and tidal lease sites, combined with small (ca. 50-150cm) multi-rotor unmanned aerial vehicles (UAVs) are potentially most useful to collect data both on the birds and the oceanographic features (Williamson et al. 2018; Lieber et al. 2019; Appendix 1, Fiigure 3). The use of a laser rangefinder such as the Vector Ornithodolite for precise horizontal positions has potential but this method needs to be fully validated for use within tidal stream environments and the influence of sea state and surface conditions assessed (Cole et al., 2019). Bird-borne bio-logging and telemetry (combined GPS and TDR) with high enough resolution (for example 2 minute intervals for GPS, 3 second intervals for TDR) is 
also useful here as location of dives is given, a behaviour that is difficult to assess by any of the above methods (Appendix 1). Importantly, data on seabird micro-habitat use needs to be combined with information on predictive variables such as bathymetry, biome, hydrodynamic features (i.e. current speed, turbulence), and prey distribution. Such assessments have been carried out for a few species at a few tidal lease sites (i.e. black guillemot ( Waggitt et al. 2016a; Johnston 2019), common guillemot (Philpott, 2013), razorbill (Philpott, 2013), Atlantic puffin (Philpott, 2013), European shag (Philpott 2013; Waggitt et al. 2016a), arctic-, common-, and sandwich S. sandvicensis terns (Lieber et al., 2019)). More such studies for more species at a wider range of sites are needed in order ensure sufficient statistical power necessary to draw generalizations (Bicknell et al., 2019).

Tidal energy devices operate underwater and therefore quantifying vertical space-use (i.e. depth) is integral to assessing collision risk (Figure 2). Data on the dive depths of vulnerable seabird species within tidal stream environments is lacking, especially in context of local bathymetry. Collecting birdborne TDR data in areas of interest is therefore a priority, as has been done for black guillemots (Masden et al. 2013). Integrated instrumentation packages could also provide some information, although not at species level and for a spatial range up to 100m (Williamson et al. 2017; Appendix 1, Table 2). Finally, the vertical dimension of the 'collision risk zone' ( $\Delta \mathrm{d}$ in Figure 2 ) has almost exclusively been considered in terms of horizontal-axis seafloor mounted turbines and this needs to be expanded to include tidal kite and floating turbines (Langton et al. 2011).

Whether seabirds dive in the vicinity of turbines $(<100 \mathrm{~m})$ and in so doing successfully evade blades or not is currently almost entirely unknown (Wilson et al. 2007; Copping et al. 2016). As such there is a need to quantify near-field underwater space use. This can be achieved through active acoustic surveys, turbine-mounted cameras, bird-borne cameras or GPS coupled with TDR and (preferably) accelerometery, as well as integrated instrumentation platforms (Appendix 1, Table 2, Figure 3). The analysis of turbine-mounted camera footage, as trialled with wave energy devices (Jackson 2014; Bicknell et al. 2019), is a priority as evasion and/or collision events are most readily identifiable with this method. Quantifying the prevalence of conveyor belt foraging near turbines also merited as the 
prevalence of this behaviour will influence detection probability. Methods best suited for detecting this are bird-borne GPS and TDR, as well as focal watches from shore (Table 2).

Risk of blade strike is greatest during times of peak flow, that is, periods during the tidal phase when water levels are rising or falling (i.e. ebbing or flooding tide). As studies so far suggest that tidal phase affinity is species- and site-specific, the underlying factors dictating site-use need to be identified (i.e. hydrodynamic features, prey behaviour). Surveys also need to be conducted throughout the annual cycle to capture the full range of tidal phases (e.g. diurnal ebb/flood, fortnightly spring/neap) and seasonality of seabird use (e.g. breeding, moult, over-wintering). As a wide range of spatio-temporal scales and variables need to be measured, therefore, a combination of survey methods is the most suitable approach (Table 2, Figure 3). For example, conducting boat surveys coupled with vessel-mounted active acoustic measurements (Waggitt et al. 2016b) or simultaneous vantage point or unmanned aerial vehicle and active acoustic surveys (Williamson et al. 2018; Lieber et al. 2019).

\subsection{Displacement}

Determining whether displacement occurs is challenging due to the limited number and small spatial footprint of operational devices currently deployed in a few tidal lease sites (Fox et al., 2018). Studies explicitly comparing habitat use before and after deployment of operational devices are therefore necessary. Analysis of any long-term presence and abundance data gathered at the few well-studied sites containing tidal turbines (i.e. Bluemull Sound, Fall of Warness, Inner Sound, Strangford Lough, Figure 1) will provide some insight, although as the principal survey method (landbased vantage point surveys, Table 1) is unstandardised (Waggitt, Bell, and Scott 2014), comparison of datasets will be challenging. Identifying the underlying mechanism(s) which influence successful seabird foraging, including the prevalence of conveyor belt foraging and associations with particular hydrodynamic features in tidal stream environments may allow for the effect of any changes in hydrodynamics by tidal energy devices on seabirds to be predicted ( Zamon, 2003; Ladd et al., 2005; Scott et al., 2014). The evaluation of cumulative (e.g. effects of multiple devices and arrays) and 
interacting effects (e.g. turbines as fish aggregating devices) is a further challenge (Shields et al. 2009; 2011; Frid et al. 2011; Broadhurst, Barr, and Orme 2014; Roche et al. 2016; Fox et al. 2018; Fraser et al. 2018; Goyert et al. 2018; Williamson et al. 2019; Whitton et al. 2020). As discussed in the context of collision risk above, this will necessitate combining methods that can assess both habitat-scale and fine-scale variables, including surface features such as boils or wakes. In terms of disturbance, information on the sensitivity of seabird species to marine activity associated with tidal energy deployment year-round can be gathered via land-based, boat-based and aerial surveys (Long, 2017; Jarrett et al., 2018). GPS tracking could provide fine-scale resolution data during the breeding season of the responses of seabirds to vessels, if vessel tracks are available. Finally, the potential for barrier effects will depend on whether seabirds evade turbine blades and the energetic cost of this action, which can be ascertained using bird-borne cameras, in conjunction with GPS and accelerometry (Appendix 1, Table 2, Figure 3).

\section{Conclusion}

While there at least 42 studies on seabird use of tidal stream environments (Table 1), there is little synthesis of what the results mean for collision risk and displacement due to tidal energy devices, leading to calls for more information and explicit guidelines (Copping et al., 2016; ICES Special Request Advice, 2019). To this end, a conceptual framework to aid in decision-making and method-selection of monitoring of seabirds at tidal stream marine renewable energy development sites was developed and is presented here (summarised in Table 2). Following a literature review in the context of this framework, it is clear that the major knowledge gaps relate to close-range overlap $(<100 \mathrm{~m}, \Delta \mathrm{h} \times \Delta \mathrm{d}$ in Figure 2) and behaviour (i.e. evasion) as well as the variables that predict seabird use of tidal stream environments (e.g. habitat, prey behaviour, hydrodynamic features). While effects from tidal energy devices are likely to vary between sites, species and seasons, a greater understanding of factors influencing collision will also contribute to assessment of displacement effects and vice versa (Shields et al. 2009; Bonar, Bryden, and Borthwick 2015; Fox et al. 2018). The ideal strategy to address effects of interest at multiple interacting scales is to combine survey methodologies. This will necessitate 
greater interdisciplinary collaboration, as has been called for previously, especially between engineering fields (e.g. computer vision, signal processing) and ecologists (Gill 2005; Cada et al. 2007; Joslin, Polagye, and Parker-Stetter 2012; Polagye et al. 2014; Cotter, Murphy, and Polagye 2017; Weinstein 2018). Ultimately, local effects on individuals or groups need to be up-scaled to impacts on populations in order to be useful from a consenting and regulatory perspective (Boehlert and Gill, 2010; Roche et al., 2016; May et al., 2019). This will require putting tidal stream environment use by seabirds in the wider context of adult breeding success, energetics, fecundity, juvenile recruitment, and degree of individual heterogeneity (e.g. age, sex, specialization) (Daunt et al., 2007; Camphuysen et al., 2015; Ceia and Ramos, 2015). The ongoing development of habitat models that integrate data from multiple survey types (Louzao et al. 2009; Yamamoto et al. 2015; Watanuki et al. 2016) should encourage combining methods where possible for information on seabird habitat use at individual and population levels over multiple scales (Waggitt et al. 2016b; Lieber et al. 2019; Phillips et al. 2019).

\section{Acknowledgements}

This work was funded by the Bryden Centre project, supported by the European Union's INTERREG VA Programme, managed by the Special EU Programmes Body (SEUPB). The views and opinions expressed in this paper do not necessarily reflect those of the European Commission or the Special EU Programmes Body (SEUPB). Thanks to E. Benninghaus, Dr. T. Evans, S. Langlois Lopez, S. Sjöstrand for comments on earlier versions of the manuscript and/or graphics support. 
2 Table 1. Studies assessing seabird use of tidal stream environments, knowledge contributed within the tidal energy device effect conceptual framework, and

3 survey methods used. For search strings and further details on survey methodologies see Appendix 1.

\begin{tabular}{|c|c|c|c|c|c|c|}
\hline Author & Year & Type & Location(s) & Seabird (family level) & Type of knowledge contributed & Survey method used \\
\hline Cole et al. & 2019 & $\begin{array}{l}\text { Peer-reviewed } \\
\text { publication }\end{array}$ & $\begin{array}{l}\text { Ramsey Sound, Irish/Celtic } \\
\text { Sea, UK }\end{array}$ & $\begin{array}{l}\text { Alcidae, Laridae, } \\
\text { Phalacrocoridae, } \\
\text { Sulidae }\end{array}$ & $\begin{array}{l}\text { Spatial (micro-habitat), temporal (tidal } \\
\text { cycle) }\end{array}$ & Land-based \\
\hline Lieber et al. & 2019 & $\begin{array}{l}\text { Peer-reviewed } \\
\text { publication }\end{array}$ & $\begin{array}{l}\text { Strangford Lough, } \\
\text { Northern Ireland, UK }\end{array}$ & Laridae & $\begin{array}{l}\text { Spatial (micro-habitat), temporal (tidal } \\
\text { cycle) }\end{array}$ & Land-based, aerial (UAV) \\
\hline Goodman & 2019 & Report & $\begin{array}{l}\text { Llŷn Peninsula, North } \\
\text { Wales, UK }\end{array}$ & $\begin{array}{l}\text { Laridae, Alcidae, } \\
\text { Sulidae }\end{array}$ & $\begin{array}{l}\text { Spatial (micro-habitat), temporal (tidal } \\
\text { cycle) }\end{array}$ & Land-based \\
\hline Johnston & 2019 & PhD thesis & $\begin{array}{l}\text { North Ronaldsay, } \\
\text { Shapinsay, Stroma }\end{array}$ & Alcidae & $\begin{array}{l}\text { Spatial (habitat, micro-habitat), } \\
\text { temporal (tidal cycle) }\end{array}$ & Bird-borne telemetry (GPS) \\
\hline Jarrett et al. & 2018 & Report & $\begin{array}{l}\text { Orkney, Western Isles } \\
\text { (UK) }\end{array}$ & $\begin{array}{l}\text { Alcidae, Anatidae, } \\
\text { Gavidae, } \\
\text { Phalacrocoridae }\end{array}$ & $\begin{array}{l}\text { Spatial (habitat), displacement } \\
\text { (disturbance) }\end{array}$ & Land-based, boat-based \\
\hline Urmy \& Warren & 2018 & $\begin{array}{l}\text { Peer-reviewed } \\
\text { publication }\end{array}$ & $\begin{array}{l}\text { Great Gull Island, New } \\
\text { York, USA }\end{array}$ & Laridae & Spatial (micro-habitat) & Marine radar \\
\hline Walker \& Taylor & 2018 & Report & $\begin{array}{l}\text { Minas Passage, Bay of } \\
\text { Fundy, Nova Scotia, } \\
\text { Canada }\end{array}$ & NA & $\begin{array}{l}\text { Spatial (habitat), temporal (seasonal, } \\
\text { tidal) }\end{array}$ & Marine radar \\
\hline FORCE & 2018 & Report & $\begin{array}{l}\text { Minas Passage, Bay of } \\
\text { Fundy, Nova Scotia, } \\
\text { Canada }\end{array}$ & $\begin{array}{l}\text { Alcidae, Anatidae, } \\
\text { Gaviidae, Laridae, } \\
\text { Phalacrocoridae, } \\
\text { Sulidae }\end{array}$ & Spatial (habitat), temporal (seasonal) & Land-based \\
\hline Long & 2017 & Report & $\begin{array}{l}\text { Fall of Warness, Orkney, } \\
\text { UK }\end{array}$ & $\begin{array}{l}\text { Alcidae, Anatidae, } \\
\text { Gavidae, } \\
\text { Phalacrocoridae }\end{array}$ & $\begin{array}{l}\text { Spatial (micro-habitat, depth), } \\
\text { temporal (seasonal, tidal cycle), } \\
\text { displacement (disturbance) }\end{array}$ & Land-based \\
\hline McCann et al. & 2017 & $\begin{array}{l}\text { Peer-reviewed } \\
\text { publication }\end{array}$ & $\begin{array}{l}\text { Fall of Warness, Orkney, } \\
\text { UK }\end{array}$ & NA & Spatial (habitat, micro-habitat) & Marine radar \\
\hline
\end{tabular}




\begin{tabular}{|c|c|c|c|c|c|c|}
\hline Waggitt et al. & 2017 & $\begin{array}{l}\text { Peer-reviewed } \\
\text { publication }\end{array}$ & $\begin{array}{l}\text { Bluemull Sound, Yell, } \\
\text { Shetland; Rousay Sound, } \\
\text { Rousay, Orkney; The Fall } \\
\text { of Warness, Eday, Orkney; } \\
\text { Inner Sound, Stroma, } \\
\text { Caithness; Kylerhea, Isle } \\
\text { of Skye, Inner Hebrides; } \\
\text { Sound of Islay, Islay, Inner } \\
\text { Hebrides }\end{array}$ & $\begin{array}{l}\text { Alcidae, } \\
\text { Phalacrocoridae }\end{array}$ & $\begin{array}{l}\text { Spatial (micro-habitat), temporal (tidal } \\
\text { cycle) }\end{array}$ & Land-based \\
\hline $\begin{array}{l}\text { Williamson et } \\
\text { al. }\end{array}$ & 2017 & $\begin{array}{l}\text { Peer-reviewed } \\
\text { publication }\end{array}$ & $\begin{array}{l}\text { Fall of Warness, Orkney, } \\
\text { UK }\end{array}$ & NA & Spatial (close-range) & $\begin{array}{l}\text { Active acoustic, integrated } \\
\text { instrumentation platform }\end{array}$ \\
\hline Robbins & 2017 & $\mathrm{PhD}$ thesis & Bluemull Sound, Shetland & $\begin{array}{l}\text { Alcidae, Anatidae, } \\
\text { Gaviidae, Laridae, } \\
\text { Phalacrocoridae, } \\
\text { Stercorariidae, } \\
\text { Sulidae }\end{array}$ & $\begin{array}{l}\text { Spatial (habitat, micro-habitat), } \\
\text { temporal (seasonal, tidal cycle) }\end{array}$ & Land-based \\
\hline Fairhead tidal & 2017 & Report & $\begin{array}{l}\text { Fair \& Torr Head, } \\
\text { Northern Ireland, UK }\end{array}$ & $\begin{array}{l}\text { Alcidae, Anatidae, } \\
\text { Phalacrocoridae }\end{array}$ & Spatial (habitat, micro-habitat) & Land-based, boat-based \\
\hline Waggitt et al. & $2016 a$ & $\begin{array}{l}\text { Peer-reviewed } \\
\text { publication }\end{array}$ & $\begin{array}{l}\text { Fall of Warness, Orkney, } \\
\text { UK }\end{array}$ & $\begin{array}{l}\text { Alcidae, } \\
\text { Phalacrocoridae }\end{array}$ & $\begin{array}{l}\text { Spatial (habitat, micro-habitat, depth), } \\
\text { temporal (tidal cycle) }\end{array}$ & Land-based \\
\hline Waggitt et al. & $2016 b$ & $\begin{array}{l}\text { Peer-reviewed } \\
\text { publication }\end{array}$ & $\begin{array}{l}\text { Fall of Warness, Orkney, } \\
\text { UK }\end{array}$ & $\begin{array}{l}\text { Alcidae, } \\
\text { Phalacrocoridae }\end{array}$ & $\begin{array}{l}\text { Spatial (habitat, micro-habitat), } \\
\text { temporal (tidal cycle, seasonal) }\end{array}$ & Boat-based \\
\hline $\begin{array}{l}\text { Warwick-Evans } \\
\text { et al. }\end{array}$ & 2016 & $\begin{array}{l}\text { Peer-reviewed } \\
\text { publication }\end{array}$ & $\begin{array}{l}\text { Alderney, Channel Islands, } \\
\text { UK }\end{array}$ & $\begin{array}{l}\text { Alcidae, Laridae, } \\
\text { Phalacrocoridae }\end{array}$ & $\begin{array}{l}\text { Spatial (habitat, micro-habitat), } \\
\text { temporal (tidal cycle) }\end{array}$ & Land-based \\
\hline Wade & 2015 & $\mathrm{PhD}$ thesis & $\begin{array}{l}\text { Inner Sound, Stroma, } \\
\text { Caithness, UK }\end{array}$ & $\begin{array}{l}\text { Alcidae, Anatidae, } \\
\text { Gaviidae, Laridae, } \\
\text { Phalacrocoridae, } \\
\text { Procellariidae, } \\
\text { Stercorariidae, } \\
\text { Sulidae }\end{array}$ & $\begin{array}{l}\text { Spatial (habitat, micro-habitat), } \\
\text { temporal (seasonal) }\end{array}$ & Land-based \\
\hline Savidge et al. & 2014 & Book chapter & $\begin{array}{l}\text { Strangford Lough, } \\
\text { Northern Ireland, UK }\end{array}$ & $\begin{array}{l}\text { Alcidae, Anatidae, } \\
\text { Laridae, } \\
\text { Phalacrocoridae, } \\
\text { Sulidae }\end{array}$ & Spatial (habitat) & Land-based \\
\hline
\end{tabular}




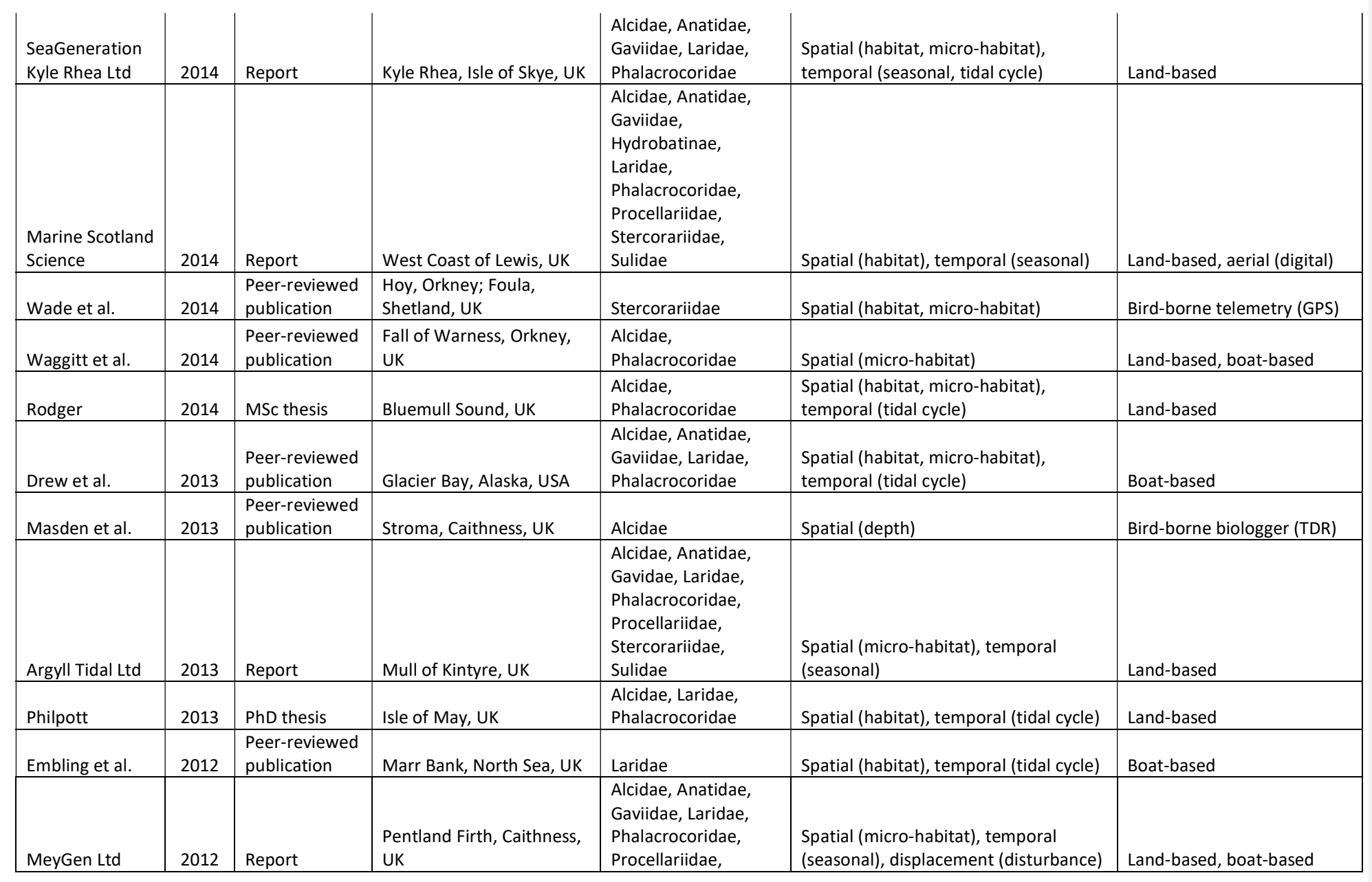




\begin{tabular}{|c|c|c|c|c|c|c|}
\hline & & & & $\begin{array}{l}\text { Stercorariidae, } \\
\text { Sulidae }\end{array}$ & & \\
\hline Robbins & 2012 & Report & $\begin{array}{l}\text { Fall of Warness, Orkney, } \\
\text { UK }\end{array}$ & $\begin{array}{l}\text { Alcidae, Anatidae, } \\
\text { Gaviidae, } \\
\text { Phalacrocoridae, } \\
\text { Sulidae }\end{array}$ & $\begin{array}{l}\text { Spatial (habitat, micro-habitat), } \\
\text { temporal (tidal cycle) }\end{array}$ & Land-based \\
\hline Royal Haskoning & 2011 & Report & $\begin{array}{l}\text { Strangford Lough, } \\
\text { Northern Ireland, UK }\end{array}$ & $\begin{array}{l}\text { Alcidae, Anatidae, } \\
\text { Laridae, } \\
\text { Phalacrocoridae }\end{array}$ & $\begin{array}{l}\text { Spatial (habitat, micro-habitat), } \\
\text { temporal (seasonal, tidal cycle) }\end{array}$ & Land-based \\
\hline RPS & 2011 & Report & $\begin{array}{l}\text { Carmel Head, Anglesey; } \\
\text { Ramsey Island SW Wales, } \\
\text { UK }\end{array}$ & $\begin{array}{l}\text { Alcidae, Anatidae, } \\
\text { Gavidae, Laridae, } \\
\text { Phalacrocoridae, } \\
\text { Procellariidae, } \\
\text { Stercorariidae, } \\
\text { Sulidae }\end{array}$ & $\begin{array}{l}\text { Spatial (habitat, micro-habitat), } \\
\text { temporal (seasonal, tidal cycle) }\end{array}$ & Land-based, boat-based \\
\hline Raya Rey & 2010 & $\begin{array}{l}\text { Peer-reviewed } \\
\text { publication }\end{array}$ & Beagle Channel, Argentina & Spheniscidae & Spatial (habitat), temporal (tidal cycle) & $\begin{array}{l}\text { Bird-borne } \\
\text { biologger/telemetry (TDR, } \\
\text { GPS) }\end{array}$ \\
\hline Mateos et al. & 2010 & $\begin{array}{l}\text { Peer-reviewed } \\
\text { publication }\end{array}$ & $\begin{array}{l}\text { The Strait of Gibraltar, } \\
\text { Spain }\end{array}$ & $\begin{array}{l}\text { Alcidae, } \\
\text { Procellariidae, } \\
\text { Sulidae, } \\
\text { Stercorariidae }\end{array}$ & Spatial (habitat) & Land-based, radar \\
\hline $\begin{array}{l}\text { ScottishPower } \\
\text { Renewables }\end{array}$ & 2010 & Report & Sound of Islay, UK & $\begin{array}{l}\text { Alcidae, Anatidae, } \\
\text { Gaviidae, } \\
\text { Hydrobatinae, } \\
\text { Laridae, } \\
\text { Phalacrocoridae, } \\
\text { Procellariidae, } \\
\text { Sulidae, } \\
\text { Stercorariidae }\end{array}$ & $\begin{array}{l}\text { Spatial (habitat, micro-habitat), } \\
\text { temporal (tidal cycle), displacement } \\
\text { (disturbance) }\end{array}$ & Land-based \\
\hline Ladd et al. & 2005 & $\begin{array}{l}\text { Peer-reviewed } \\
\text { publication }\end{array}$ & $\begin{array}{l}\text { Aleutian Islands, Bering } \\
\text { Sea, USA }\end{array}$ & $\begin{array}{l}\text { Alcidae, } \\
\text { Procellariidae }\end{array}$ & $\begin{array}{l}\text { Spatial (habitat, micro-habitat), } \\
\text { temporal (tidal cycle) }\end{array}$ & Boat-based \\
\hline Zamon & 2003 & $\begin{array}{l}\text { Peer-reviewed } \\
\text { publication }\end{array}$ & $\begin{array}{l}\text { San Juan Islands, } \\
\text { Washington State, USA }\end{array}$ & $\begin{array}{l}\text { Alcidae, Laridae, } \\
\text { Phalacrocoridae }\end{array}$ & $\begin{array}{l}\text { Spatial (habitat, micro-habitat), } \\
\text { temporal (tidal cycle) }\end{array}$ & Land-based, aerial \\
\hline
\end{tabular}




\begin{tabular}{|l|c|l|l|l|l|l|} 
Holm \& Burger & 2002 & $\begin{array}{l}\text { Peer-reviewed } \\
\text { publication }\end{array}$ & $\begin{array}{l}\text { Salish Sea, Vancouver } \\
\text { Island, British Columbia, } \\
\text { Canada }\end{array}$ & $\begin{array}{l}\text { Alcidae, Anatidae, } \\
\text { Gavidae, Laridae, } \\
\text { Phalacrocoridae }\end{array}$ & $\begin{array}{l}\text { Spatial (micro-habitat), temporal (tidal } \\
\text { cycle) }\end{array}$ & Land-based, boat-based \\
\hline Hunt et al. & 1998 & $\begin{array}{l}\text { Peer-reviewed } \\
\text { publication }\end{array}$ & $\begin{array}{l}\text { Aleutian Islands, Bering } \\
\text { Sea, USA }\end{array}$ & Alcidae & Spatial (habitat, micro-habitat) & Boat-based \\
\hline Nol \& Gaskin & 1987 & $\begin{array}{l}\text { Peer-reviewed } \\
\text { publication }\end{array}$ & Bay of Fundy, Canada & Alcidae & $\begin{array}{l}\text { Spatial (habitat, micro-habitat), } \\
\text { temporal (tidal cycle) }\end{array}$ & Land-based, boat-based \\
\hline $\begin{array}{l}\text { Braune \& } \\
\text { Gaskin }\end{array}$ & 1982 & $\begin{array}{l}\text { Peer-reviewed } \\
\text { publication }\end{array}$ & New Brunswick, USA & Laridae & $\begin{array}{l}\text { Spatial (habitat, micro-habitat), } \\
\text { temporal (seasonal, tidal cycle) }\end{array}$ & Boat-based \\
\hline
\end{tabular}


Table 2. Methods for monitoring seabird distribution and behaviour at tidal stream environments and the component(s) within the tidal energy device effect 6 conceptual framework for which each is most appropriate

\begin{tabular}{|c|c|c|c|c|c|c|c|c|c|c|c|c|}
\hline & & \multicolumn{8}{|c|}{ Collision risk } & \multicolumn{3}{|c|}{ Displacement } \\
\hline & & \multicolumn{4}{|c|}{ Spatial overlap } & \multicolumn{3}{|c|}{ Temporal } & \multirow{2}{*}{\begin{tabular}{|l|} 
Behaviour \\
Evasion \\
\end{tabular}} & \multirow[b]{2}{*}{$\begin{array}{l}\text { Habitat/prey } \\
\text { modification }\end{array}$} & \multirow[b]{2}{*}{ Disturbance } & \multirow[b]{2}{*}{ Barrier } \\
\hline & & $>1 \mathrm{~km}$ & $<1 \mathrm{~km}$ & $<100 \mathrm{~m}$ & Depth & $\begin{array}{l}\text { Tidal } \\
\text { cycle }\end{array}$ & Seasonal & Annual & & & & \\
\hline \multicolumn{2}{|c|}{ Method } & & & & & & & & & & & \\
\hline Vantage-point survey & & $\checkmark$ & $\checkmark$ & & & $\checkmark$ & $\checkmark$ & $\checkmark$ & & & $\checkmark$ & $\checkmark$ \\
\hline Boat-based survey & & $\checkmark$ & & & & $\checkmark$ & $\checkmark$ & $\checkmark$ & & & $\checkmark$ & $\checkmark$ \\
\hline \multicolumn{13}{|l|}{ Aerial survey } \\
\hline & Visual/digital & $\checkmark$ & $\checkmark$ & & & $\checkmark$ & $\checkmark$ & $\checkmark$ & & & $\checkmark$ & $\checkmark$ \\
\hline & UAV & & $\checkmark$ & $\checkmark$ & & $\checkmark$ & $\checkmark$ & $\checkmark$ & & $\checkmark$ & $\checkmark$ & \\
\hline Active acoustic & & & & $\checkmark$ & $\checkmark$ & & & & $\checkmark$ & $\checkmark$ & & $\checkmark$ \\
\hline $\begin{array}{l}\text { Underwater visual } \\
\text { camera }\end{array}$ & & & & $\checkmark$ & $\checkmark$ & & & & $\checkmark$ & & & $\checkmark$ \\
\hline $\begin{array}{l}\text { Integrated } \\
\text { instrumentation } \\
\text { platforms }\end{array}$ & & & & $\checkmark$ & $\checkmark$ & $\checkmark$ & $\checkmark$ & & $\checkmark$ & $\checkmark$ & & $\checkmark$ \\
\hline \multicolumn{13}{|l|}{ Bird-borne telemetry } \\
\hline & GPS & $\checkmark$ & $\checkmark$ & $\checkmark$ & & $\checkmark$ & & & & & $\checkmark$ & $\checkmark$ \\
\hline & TDR & & & & $\checkmark$ & $\checkmark$ & $\checkmark$ & $\checkmark$ & & & & $\checkmark$ \\
\hline & Accelerometry & & & & & $\checkmark$ & & & $\checkmark$ & & & $\checkmark$ \\
\hline & Camera & & & $\checkmark$ & & $\checkmark$ & & & $\checkmark$ & $\checkmark$ & & $\checkmark$ \\
\hline
\end{tabular}


Figure 1. Tidal lease sites in the UK, and largest (top 10) breeding colonies of each of the presumed most vulnerable species to effects from tidal energy

devices (in decreasing order): razorbill, European shag, black guillemot, common guillemot, great cormorant. Inset is on an area with major UK tidal energy

development sites (Inner Sound, Fall of Warness).

\section{$\wedge$}

Seabird colony

$\triangle$ Tidal lease site location
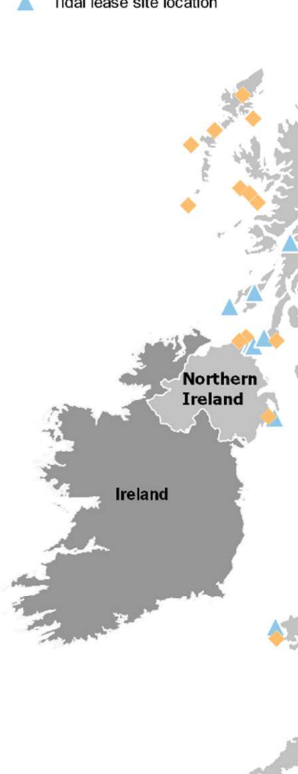
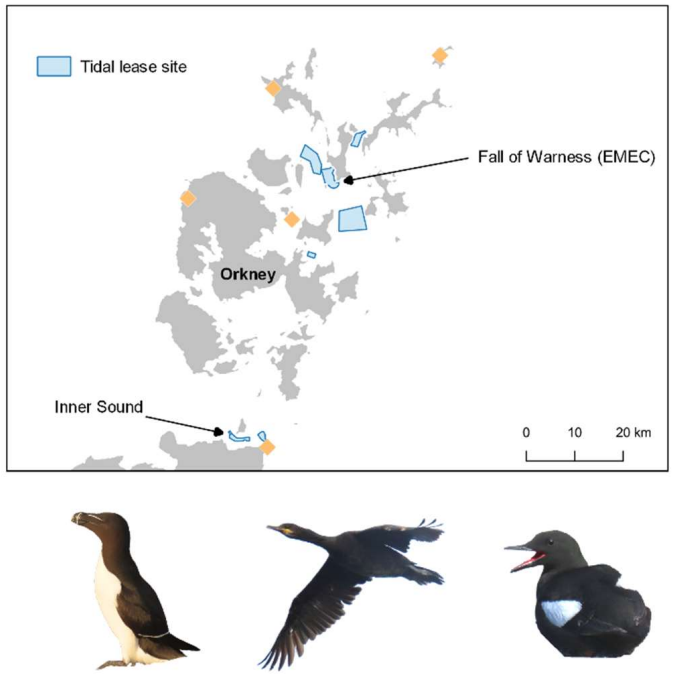

Razorbill (A.torda) European shag (P. aristotellis) Black guillemot (C. grylle)

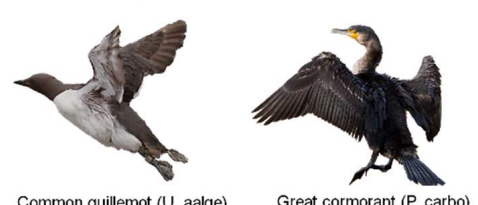

Common guillemot (U. aalge) Great cormorant (P. carbo) 

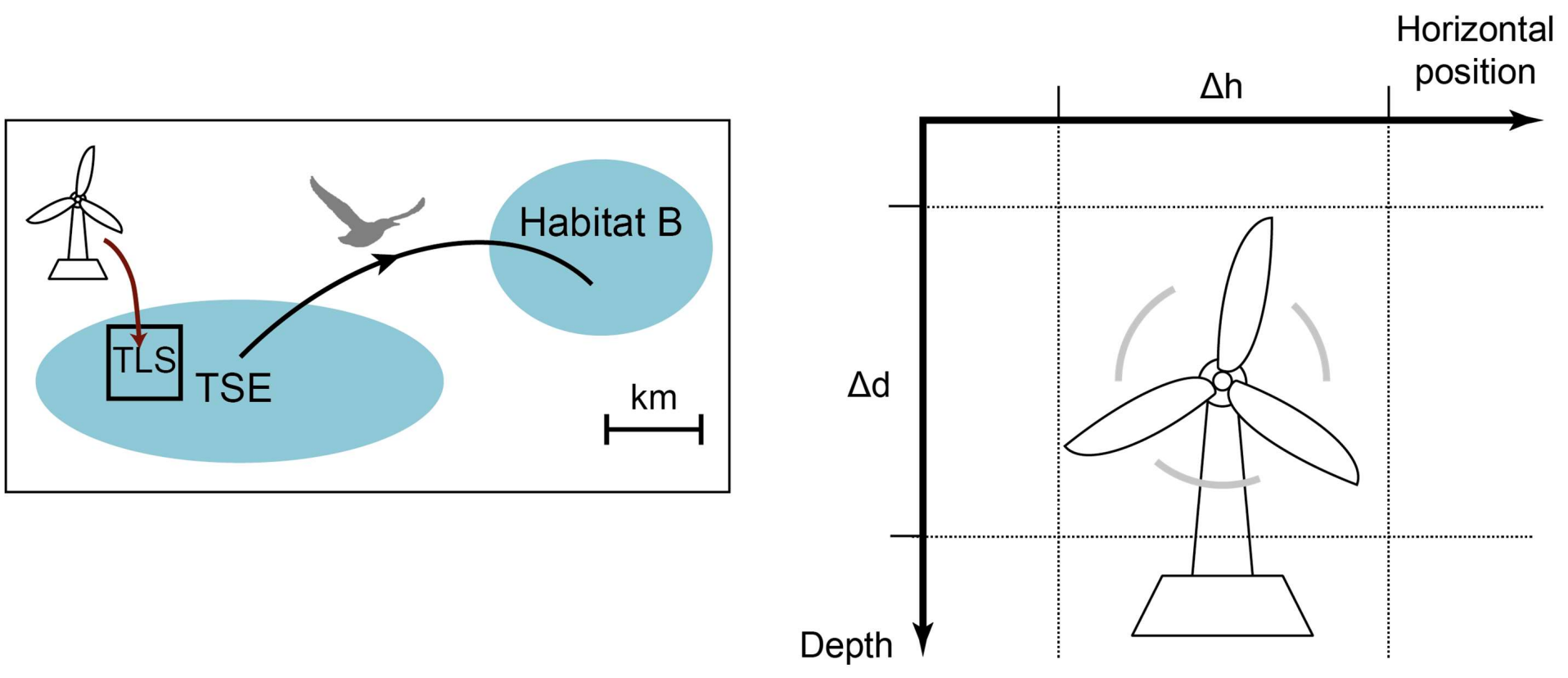
Figure 3. "Tools of the trade": commonly used and novel seabird survey techniques available to assess use of tidal stream environments and interactions with

instrumentation platform, F: Marine radar, G: Bird-borne biologging/telemetry

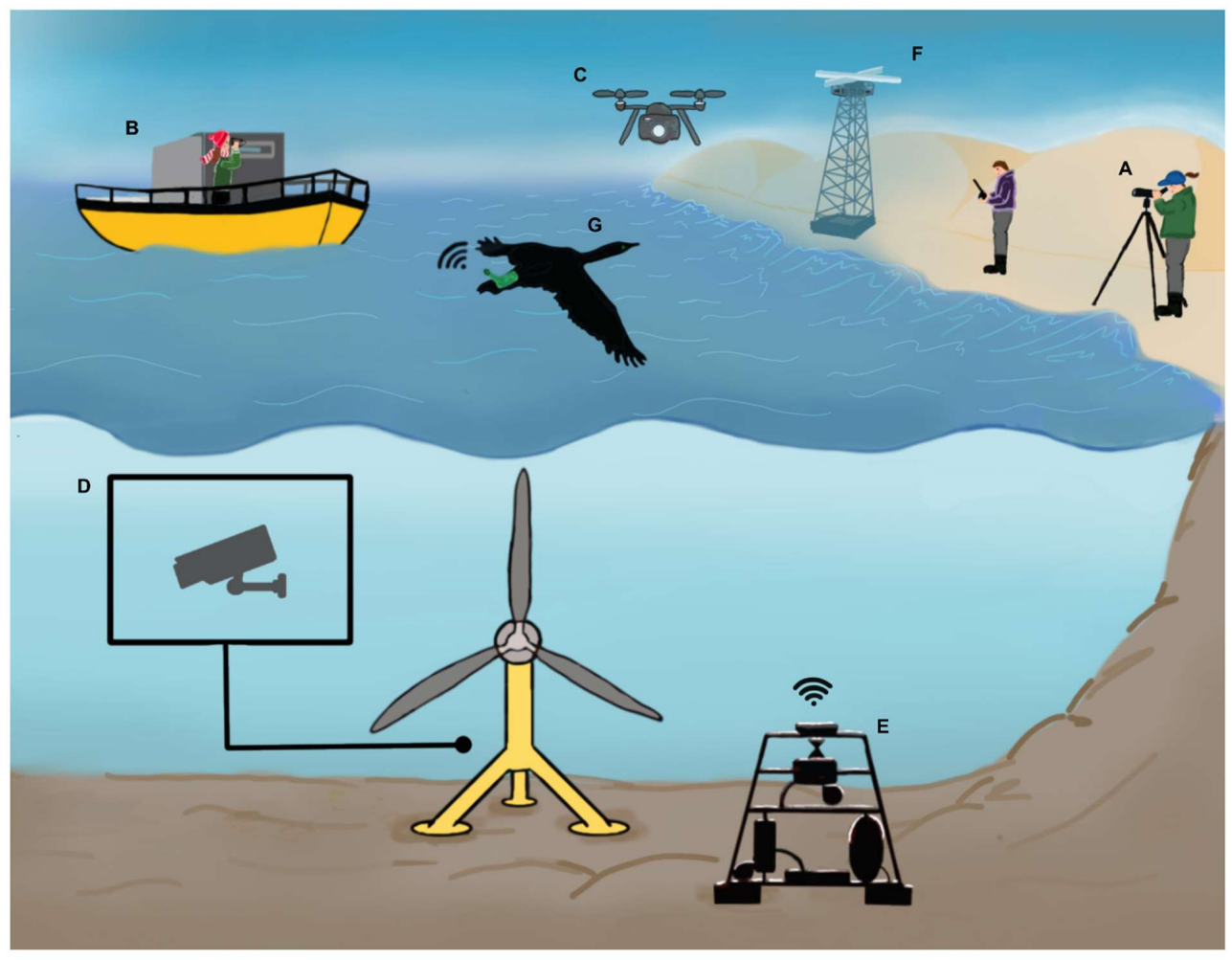




\section{References}

Argyll Tidal Ltd, 2013. Environmental Appraisal (EA) for the Argyll Tidal Demonstrator Project. Argyll Tidal Demonstr. Proj. December, 1-207.

Becker, P.H., Frank, D., Sudmann, S.R., 1993. Temporal and spatial pattern of common tern (Sterna hirundo) foraging in the Wadden Sea. Oecologia 93, 389-393.

Benjamins, S., Dale, A., Hastie, G., Waggitt, J., Lea, M.-A., Scott, B., Wilson, B., 2015. Confusion Reigns? A Review of Marine Megafauna Interactions with Tidal-Stream Environments. Oceanogr. Mar. Biol. 1-54. https://doi.org/10.1201/b18733-2

Bicknell, A.W.J., Sheehan, E. V., Godley, B.J., Doherty, P.D., Witt, M.J., 2019. Assessing the impact of introduced infrastructure at sea with cameras: A case study for spatial scale, time and statistical power. Mar. Environ. Res. https://doi.org/10.1016/J.MARENVRES.2019.04.007 Boehlert, G.W., Gill, A.B., 2010. Environmental and ecological effects of ocean renewable energy development: a current synthesis. Oceanography 23, 68-81.

Bonar, P.A.J., Bryden, I.G., Borthwick, A.G.L., 2015. Social and ecological impacts of marine energy development. Renew. Sustain. Energy Rev. 47, 486-495.

https://doi.org/10.1016/j.rser.2015.03.068

Bradbury, G., Trinder, M., Furness, B., Banks, A.N., Caldow, R.W.G., Hume, D., 2014. Mapping Seabird Sensitivity to offshore wind farms. PLoS One 9. https://doi.org/10.1371/journal.pone.0106366 Braune, B.M., Gaskin, D.E., 1982. Feeding Ecology of Nonbreeding Populations of Larids off Deer Island, New Brunswick. Auk 99, 67-76.

Broadhurst, M., Barr, S., Orme, C.D.L., 2014. In-situ ecological interactions with a deployed tidal energy device; an observational pilot study. Ocean Coast. Manag. 99, 31-38.

https://doi.org/10.1016/J.OCECOAMAN.2014.06.008

Broadhurst, M., Orme, C.D.L., 2014. Spatial and temporal benthic species assemblage responses with a deployed marine tidal energy device: A small scaled study. Mar. Environ. Res. 99, 76-84. https://doi.org/10.1016/j.marenvres.2014.03.012 
Bryden, I., Melville, G.T., 2004. Choosing and evaluating sites for tidal current development. Proc. Inst. Mech. Eng. Part A J. Power Energy 218, 567-577. https://doi.org/10.1243/0957650042584375

Cada, G., Ahlgrimm, J., Bahleda, M., Bigford, T., Stavrakas, S.D., Hall, D., Moursund, R., Sale, M., 2007. Potential impacts of hydrokinetic and wave energy conversion technologies on aquatic environments. Fisheries 32, 174-181.

Camphuysen, K.C.J., Shamoun-Baranes, J., Van Loon, E.E., Bouten, W., 2015. Sexually distinct

foraging strategies in an omnivorous seabird. Mar. Biol. 162, 1417-1428.

https://doi.org/10.1007/s00227-015-2678-9

Ceia, F.R., Ramos, J.A., 2015. Individual specialization in the foraging and feeding strategies of seabirds: a review. Mar. Biol. 162, 1923-1938. https://doi.org/10.1007/s00227-015-2735-4

Chimienti, M., Cornulier, T., Owen, E., Bolton, M., Davies, I.M., Travis, J.M.J., Scott, B.E., 2016. The use of an unsupervised learning approach for characterizing latent behaviors in accelerometer data. Ecol. Evol. 6, 727-741. https://doi.org/10.1002/ece3.1914

Climate Change Act, 2019. Climate Change (Emissions Reduction Targets) (Scotland) Act. The Scottish Parliament.

Cole, E.L., Waggitt, J.J., Hedenstrom, A., Piano, M., Holton, M.D., Börger, L., Shepard, E.L.C., 2019. The Ornithodolite as a tool to quantify animal space use and habitat selection: a case study with birds diving in tidal waters. Integr. Zool. 14, 4-16. https://doi.org/10.1111/17494877.12327

Cook, A.S.C.P., Humphreys, E.M., Masden, E.A., Burton, N.H.K., 2014. The Avoidance Rates of Collision Between Birds and Offshore Turbines. Scottish Mar. Freshw. Sci. 5.

Copping, A., Sather, N., Hannah, L., Whiting, J., Zydlewski, G., Staines, G., Gill, A., Hutchinson, I., A, O., Simas, T., Bald, J., Sparling, C., Wood, J., Masden, E., 2016. Annex IV 2016 State of the Science Report: Environmental Effects of Marine Renewable Energy Development Around the World, State of the Science Report. https://doi.org/10.1097/JNN.0b013e3182829024 
Cotter, E., Murphy, P., Polagye, B., 2017. Benchmarking sensor fusion capabilities of an integrated instrumentation package. Int. J. Mar. Energy 20, 64-79. https://doi.org/10.1016/J.IJOME.2017.09.003

Cox, S.L., Scott, B.E., Camphuysen, C.J., 2013. Combined spatial and tidal processes identify links between pelagic prey species and seabirds. Mar. Ecol. Prog. Ser. 479, 203-221. https://doi.org/10.3354/meps10176

Dannheim, J., Bergström, L., Birchenough, S.N.R., Brzana, R., Boon, A.R., Coolen, J.W.P., Dauvin, J.-C.,

De Mesel, I., Derweduwen, J., Gill, A.B., Hutchison, Z.L., Jackson, A.C., Janas, U., Martin, G., Raoux, A., Reubens, J., Rostin, L., Vanaverbeke, J., Wilding, T.A., Wilhelmsson, D., Degraer, S., 2019. Benthic effects of offshore renewables: identification of knowledge gaps and urgently needed research. ICES J. Mar. Sci. https://doi.org/10.1093/icesjms/fsz018

Daunt, F., Wanless, S., Harris, M., Money, L., Monaghan P, 2007. Older and wiser: improvements in breeding success are linked to better foraging performance in European shags. Funct. Ecol. 21, $561-567$.

Desholm, M., Kahlert, J., 2005. Avian collision risk at an offshore wind farm. Biol. Lett. 1, 296-298. https://doi.org/10.1098/rsbl.2005.0336

Dias, M.P., Martin, R., Pearmain, E.J., Burfield, I.J., Small, C., Phillips, R.A., Yates, O., Lascelles, B., Borboroglu, P.G., Croxall, J.P., 2019. Threats to seabirds: A global assessment. Biol. Conserv. https://doi.org/10.1016/j.biocon.2019.06.033

Drew, G.S., Piatt, J.F., Hill, D.F., 2013. Effects of currents and tides on fine-scale use of marine bird habitats in a Southeast Alaska hotspot. Mar. Ecol. Prog. Ser. 487, 275-286. https://doi.org/10.3354/meps10304

Edenhofer, O., Pichs-Madruga, R., Sokona, Y., Seyboth, K., Matschoss, P., Kadner, S., Zwickel, T., 2011. The IPCC Special Report on Renewable Energy Sources and Climate Change Mitigation. Cambridge.

Embling, C.B., Illian, J., Armstrong, E., van der Kooij, J., Sharples, J., Camphuysen, K.C.J., Scott, B.E., 
2012. Investigating fine-scale spatio-temporal predator-prey patterns in dynamic marine ecosystems: A functional data analysis approach. J. Appl. Ecol. 49, 481-492.

https://doi.org/10.1111/j.1365-2664.2012.02114.x

Enders, E.C., Boisclair, D., Roy, A.G., 2003. The effect of turbulence on the cost of swimming for juvenile Atlantic salmon (Salmo salar) 1. https://doi.org/10.1139/F03-101

Enstipp, M.R., Grémillet, D., Jones, D.R., 2007. Investigating the functional link between prey abundance and seabird predatory performance. Mar. Ecol. Prog. Ser. 331, 267-279.

Esteban, M., Leary, D., 2012. Current developments and future prospects of offshore wind and ocean energy. Appl. Energy 90, 128-136. https://doi.org/10.1016/j.apenergy.2011.06.011 European Commission, 2013. Natura 2000 Directive 29, 1-58.

Fairhead tidal, 2017. Fair Head Tidal Energy Park: Consent Application.

Fauchald, P., 2009. Spatial interaction between seabirds and prey: review and synthesis. Mar. Ecol. Prog. Ser. 391, 139-151. https://doi.org/10.3354/meps07818

FORCE, 2018. Environmental Effects Monitoring Program 2018 Annual Report. Halifax, Nova Scotia. Fox, C.J., Benjamins, S., Masden, E.A., Miller, R., 2018. Challenges and opportunities in monitoring the impacts of tidal-stream energy devices on marine vertebrates. Renew. Sustain. Energy Rev. 81, 1926-1938. https://doi.org/10.1016/j.rser.2017.06.004

Fraenkel, P.L., 2006. Tidal current energy technologies. Ibis (Lond. 1859). 148, 145-151. https://doi.org/10.1111/j.1474-919X.2006.00518.x

Fraser, S., Williamson, B.J., Nikora, V., Scott, B.E., 2018. Fish distributions in a tidal channel indicate the behavioural impact of a marine renewable energy installation. Energy Reports 4, 65-69. https://doi.org/10.1016/J.EGYR.2018.01.008

Frederiksen, M., Moe, B., Daunt, F., Phillips, R.A., Barrett, R.T., Bogdanova, M.I., Boulinier, T., Chardine, J.W., Chastel, O., Chivers, L.S., Christensen-Dalsgaard, S., Clément-Chastel, C., Colhoun, K., Freeman, R., Gaston, A.J., González-Solís, J., Goutte, A., Grémillet, D., Guilford, T., Jensen, G.H., Krasnov, Y., Lorentsen, S.H., Mallory, M.L., Newell, M., Olsen, B., Shaw, D., Steen, 
H., Strøm, H., Systad, G.H., Thórarinsson, T.L., Anker-Nilssen, T., 2012. Multicolony tracking reveals the winter distribution of a pelagic seabird on an ocean basin scale. Divers. Distrib. 18, 530-542. https://doi.org/10.1111/j.1472-4642.2011.00864.x

Frederiksen, M., Wanless, S., Harris, M.P., Rothery, P., Wilson, L.J., 2004. The role of industrial fisheries and oceanographic change in the decline of North Sea black-legged kittiwakes. J. Appl. Ecol. 41, 1129-1139. https://doi.org/10.1111/j.0021-8901.2004.00966.x

Frid, C., Andonegi, E., Depestele, J., Judd, A., Rihan, D., Rogers, S.I., Kenchington, E., 2012. The environmental interactions of tidal and wave energy generation devices. Environ. Impact Assess. Rev. 32, 133-139. https://doi.org/10.1016/J.EIAR.2011.06.002

Frid, C., Andonegi, E., Depestele, J., Judd, A., Rihan, D., Rogers, S.I., Kenchington, E., 2011. The environmental interactions of tidal and wave energy generation devices. Environ. Impact Assess. Rev. 32, 133-139. https://doi.org/10.1016/j.eiar.2011.06.002

Furness, R.W., Monaghan, P., 1987. Seabird Ecology. Springer US.

Furness, R.W., Wade, H.M., Robbins, A.M.C., Masden, E.A., 2012. Assessing the sensitivity of seabird populations to adverse effects from tidal stream turbines and wave energy devices. ICES J. Mar. Sci. 69, 1466-1479.

Garthe, S., Hüppop, O., 2004. Scaling possible adverse effects of marine wind farms on seabirds: developing and applying a vulnerability index. J. Appl. Ecol. 41, 724-734. https://doi.org/10.1111/j.0021-8901.2004.00918.x

Gill, A.B., 2005. Offshore renewable energy: ecological implications of generating electricity in the coastal zone. J. Appl. Ecol. 42, 605-615. https://doi.org/10.1111/j.1365-2664.2005.01060.x Gómez-Gutiérrez, J., Robinson, C.J., 2006. Tidal current transport of epibenthic swarms of the euphasiid Nyctiphanes simplex in a shallow, subtropical bay on Baja California peninsula, Mexico. Mar. Ecol. Prog. Ser. 320, 215-231.

Goodman, E., 2019. Occupancy patterns of sea birds in relation to oceanographic conditions at sites on the Llyn Peninsula. Plymouth Student Sci. 12, 25-49. 
Goyert, H.F., Gardner, B., Veit, R.R., Gilbert, A.T., Connelly, E., Duron, M., Johnson, S., Williams, K., 2018. Evaluating habitat, prey, and mesopredator associations in a community of marine birds. ICES J. Mar. Sci. 75, 1602-1612. https://doi.org/10.1093/icesjms/fsy020

Grist, H., Daunt, F., Wanless, S., Nelson, E.J., Harris, M.P., Newell, M., Burthe, S., Reid, J.M., 2014. Site Fidelity and Individual Variation in Winter Location in Partially Migratory European Shags. PLoS One 9, e98562. https://doi.org/10.1371/journal.pone.0098562

Guilford, T., Freeman, R., Boyle, D., Dean, B., Kirk, H., Phillips, R., Perrins, C., 2011. A dispersive migration in the atlantic Puffin and its implications for migratory navigation. PLoS One 6. https://doi.org/10.1371/journal.pone.0021336

Hansen, K.A., Maxwell, A., Siebert, U., Larsen, O.N., Wahlberg, M., 2017. Great cormorants (Phalacrocorax carbo) can detect auditory cues while diving. Sci. Nat. 104. https://doi.org/10.1007/s00114-017-1467-3

Haverson, D., Bacon, J., Smith, H.C.M., Venugopal, V., Xiao, Q., 2018. Modelling the hydrodynamic and morphological impacts of a tidal stream development in Ramsey Sound. Renew. Energy 126, 876-887. https://doi.org/10.1016/J.RENENE.2018.03.084

Heath, J.P., Gilchrist, H.G., 2010. When foraging becomes unprofitable: Energetics of diving in tidal currents by common eiders wintering in the Arctic. Mar. Ecol. Prog. Ser. 403, 279-290. https://doi.org/10.1007/s00381-013-2103-y Heath, J.P., Gilchrist, H.G., Ydenberg, R.C., 2006. Regulation of stroke pattern and swim speed across a range of current velocities: diving by common eiders wintering in polynyas in the Canadian Arctic. J. Exp. Biol. 209, 3974-83. https://doi.org/10.1242/jeb.02482

Holm, K.J., Burger, A.E., 2002. Foraging behaviour and resource partitioning by diving birds during winter in areas of strong tidal currents. Waterbirds 25, 312-325. https://doi.org/10.1675/15244695(2002)025[0312:FBARPB]2.0.CO;2

Hunt, G.L., Russell, R.W., Coyle, K.O., Weingartner, T., 1998. Comparative foraging ecology of planktivorous auklets in relation to ocean physics and prey availability. Mar. Ecol. Prog. Ser. 
167, 241-259.

Hunt Jr, G.L., Russell, R.W., Coyle, K.O., Weingartner, T., 1998. Comparative foraging ecology of planktivorous auklets in relation to ocean physics and prey availability. Mar. Ecol. Prog. Ser. 167, 241-259.

Hutchison, I., Morgan, P., Sheehy, J., Tait, C., 2019. Review of underwater video data collected around operating tidal turbines, Scottish Natural Heritage.

ICES, 2019. OSPAR request to advise on the current state and knowledge of studies into the deployment and environmental impacts of wet renewable technologies and marine energy storage systems, Report of the ICES Advisory Committee. https://doi.org/10.17895/ices.advice.4894

ICES Special Request Advice, 2019. OSPAR request to advise on the current state and knowledge of studies into the deployment and environmental impacts of wet renewable technologies and marine energy storage systems. https://doi.org/10.17895/ices.advice.4894

Inger, R., Attrill, M.., Bearhop, S.., Broderick, A.C.., Grecian, W.J.., Hodgson, D.J.., Mills, C.., Sheehan, E.., Votier, S.C.., Witt, M.J.., Godley, B.J., 2009. Marine renewable energy: potential benefits to biodiversity? An urgent call for research. J. Appl. Ecol. 46, 1145-1153.

Intergovernmental Panel on Climate Change, 2014. Climate Change 2014: Mitigation of Climate Change, Climate Change 2014 Mitigation of Climate Change. Cambridge University Press, Cambridge. https://doi.org/10.1017/CBO9781107415416.013

Irons, D.B., 1998. Foraging Area Fidelity of Individual Seabirds in Relation to Tidal Cycles and Flock Feeding 79, 647-655.

Jackson, A., 2014. Riding the waves: use of the Pelamis device by seabirds, in: Proceedings of the 2 nd International Conference on Environmental Interactions of Marine. Stornoway, Isle of Lewis, Outer Hebrides. https://doi.org/10.1155/2013/906180

Jarrett, D., Cook, A.S.C.P., Woodward, I., Ross, K., Horswill, C., Dadam, D., Humphreys, E.M., 2018. Short-Term Behavioural Responses of Wintering Waterbirds to Marine Activity. Scottish Mar. 
Freshw. Sci. 9. https://doi.org/10.7489/12096-1

JNCC, 2007. Report on the Species and Habitat Review Report by the Biodiversity Reporting and Information Group (BRIG) to the UK Standing Committee-5155 Report on the Species and Habitats Review.

Johansen, S., Larsen, O.N., Christensen-Dalsgaard, J., Seidelin, L., Huulvej, T., Jensen, K., Lunneryd, S., Boström, M., Wahlberg, M., 2016. In-Air and Underwater Hearing in the Great Cormorant (Phalacrocorax carbo sinensis), in: Popper, A.N., Hawkins, A. (Eds.), The Effects of Noise on Aquatic Life II. Springer Science+Business Media, New York, pp. 505-512. https://doi.org/10.1007/978-1-4939-2981-8

Johnston, D.T., 2019. Investigating the foraging ecology of black guillemots Cepphus grylle in relation to tidal stream turbines and marine protected areas. University of the Highlands and Islands. Johnston, D.W., Westgate, A.J., Read, A.J., 2005. Effects of fine-scale oceanographic features on the distribution and movements of harbour porpoises Phocoena phocoena in the Bay of Fundy. Mar. Ecol. Prog. Ser. 295, 279-293. https://doi.org/10.3354/meps295279 Joslin, J., Polagye, B., Parker-Stetter, S., 2012. Development of a stereo camera system for monitoring hydrokinetic turbines, in: OCEANS 2012 MTS/IEEE: Harnessing the Power of the Ocean. https://doi.org/10.1109/OCEANS.2012.6405043

Katzir, G., 2003. Corneal power and underwater accommodation in great cormorants (Phalacrocorax carbo sinensis). J. Exp. Biol. 206, 833-841. https://doi.org/10.1242/jeb.00142

Kirby, A.D., Hawkns, K.R., Freeman, S.M., McCall, R.A., Furness, R.W., Edhouse, E.S., 2013. Ornithological impacts. Nat. Environ. Res. Counc. (NERC), wave tidal Consent. position Pap. Ser. Lacoste, K.N., Munro, J., Castonguay, M., Saucier, F.J., Gagné, J.A., 2001. The influence of tidal streams on the pre-spawning movements of Atlantic herring, Clupea harengus L., in the St. Lawrence estuary. ICES J. Mar. Sci. 58, 1286-1298.

Ladd, C., Jahncke, J., Hunt, G.L., Coyle, K.O., Stabeno, P.J., 2005. Hydrographic features and seabird foraging in Aleutian Passes. Fish. Oceanogr. 14, 178-195. https://doi.org/10.1111/j.1365- 
2419.2005.00374.x

Langton, R., Davies, I.M., Scott, B.E., 2011. Seabird conservation and tidal stream and wave power generation: Information needs for predicting and managing potential impacts. Mar. Policy 35, 623-630. https://doi.org/10.1016/J.MARPOL.2011.02.002

Lessells, C.M., Stephens, D.W., 1983. Central place foraging: Single-prey loaders again. Anim. Behav. 31, 238-243. https://doi.org/10.1016/S0003-3472(83)80194-8

Lewis, M., Neill, S.P., Robins, P.E., Hashemi, M.R., 2015. Resource assessment for future generations of tidal-stream energy arrays. Energy 83. https://doi.org/10.1016/j.energy.2015.02.038

Lieber, L., Nimmo-Smith, W.A.M., Waggitt, J.J., Kregting, L., 2019. Localised anthropogenic wake generates a predictable foraging hotspot for top predators. Commun. Biol. 2, 123. https://doi.org/10.1038/s42003-019-0364-z

Linnebjerg, J.F., Fort, J., Guilford, T., Reuleaux, A., Mosbech, A., Frederiksen, M., 2013. Sympatric Breeding Auks Shift between Dietary and Spatial Resource Partitioning across the Annual Cycle. PLoS One 8, 1-10. https://doi.org/10.1371/journal.pone.0072987

Long, C., 2017. Analysis of the possible displacement of bird and marine mammal species related to the installation and operation of marine energy conversion systems. Scottish Nat. Herit. Comm. Rep. No. 947.

Louzao, M., Bécares, J., Rodríguez, B., Hyrenbach, K.D., Ruiz, A., Arcos, J.M., 2009. Combining vesselbased surveys and tracking data to identify key marine areas for seabirds. Mar. Ecol. Prog. Ser. 391, 183-197. https://doi.org/10.3354/meps08124

Lovvorn, J.R., 2004. Stroke patterns and regulation of swim speed and energy cost in free-ranging Brunnich's guillemots. J. Exp. Biol. 207, 4679-4695. https://doi.org/10.1242/jeb.01331 Magagna, D., Uihlein, A., 2015. Ocean energy development in Europe: Current status and future perspectives. Int. J. Mar. Energy 11, 84-104. https://doi.org/10.1016/j.ijome.2015.05.001 Marine Energy Council, 2019. UK Marine Energy 2019. Glasgow.

Marine Renewables Canada, 2018. 2018 State of the Sector Report. Mar. Renew. Energy Canada. 

determine use of seaspace in areas of potential marine renewable energy developments. Scottish Mar. Freshw. Sci. 5.

Martin-Short, R., Hill, J., Kramer, S.C., Avdis, A., Allison, P.A., Piggott, M.D., 2015. Tidal resource extraction in the Pentland Firth, UK: Potential impacts on flow regime and sediment transport in the Inner Sound of Stroma. Renew. Energy 76, 596-607. https://doi.org/10.1016/j.renene.2014.11.079

Martin, G.R., Wanless, S., 2015. The visual fields of Common Guillemots Uria aalge and Atlantic Puffins Fratercula arctica: Foraging, vigilance and collision vulnerability. Ibis (Lond. 1859). 157, 798-807. https://doi.org/10.1111/ibi.12297

Martin, G.R., White, C.R., Butler, P.J., 2008. Vision and the foraging technique of Great Cormorants Phalacrocorax carbo : pursuit or close-quarter foraging?, Ibis.

Masden, E.A., Foster, S., Jackson, A.C., 2013. Diving behaviour of Black Guillemots Cepphus grylle in the Pentland Firth, UK: Potential for interactions with tidal stream energy developments. Bird Study 60, 547-549. https://doi.org/10.1080/00063657.2013.842538

Masden, E.A., Haydon, D.T., Fox, A.D., Furness, R.W., Bullman, R., Desholm, M., 2009. Barriers to movement: Impacts of wind farms on migrating birds. ICES J. Mar. Sci. 66, 746-753. https://doi.org/10.1093/icesjms/fsp031

Mateos, M., Arroyo, G.M., Rodríguez, A., Cuenca, D., de la Cruz, A., 2010. Calibration of visually estimated distances to migrating seabirds with radar measurements. J. F. Ornithol. 81, 302309. https://doi.org/10.1111/j.1557-9263.2010.00286.x

May, R., Masden, E.A., Bennet, F., Perron, M., 2019. Considerations for upscaling individual effects of wind energy development towards population-level impacts on wildlife. J. Environ. Manage. 230, 84-93. https://doi.org/10.1016/J.JENVMAN.2018.09.062

McCann, D.L., Bell, P.S., 2017. Visualising the aspect-dependent radar cross section of seabirds over a tidal energy test site using a commercial marine radar system. Int. J. Mar. Energy 17, 56-63. 
https://doi.org/10.1016/j.ijome.2017.01.002

McCluskie, A.E., Langston, R.H.W., Wilkinson, N.I., 2013. Birds and wave \& tidal stream energy: an ecological review. RSPB Res. Rep. No. 42.

Mcinnes, A.M., Thiebault, A., Cloete, T., Pichegru, L., Aubin, T., Mcgeorge, C., Pistorius, P.A., 2019. Social context and prey composition are associated with calling behaviour in a diving seabird. Ibis (Lond. 1859). ibi.12806. https://doi.org/10.1111/ibi.12806

Melikoglu, M., 2018. Current status and future of ocean energy sources: A global review. Ocean Eng. 148, 563-573. https://doi.org/10.1016/j.oceaneng.2017.11.045

MeyGen Ltd, 2012. MeyGen Tidal Energy Project Phase 1 Environmental Statement.

Miller, R.G., Hutchison, Z.L., Macleod, A.K., Burrows, M.T., Cook, E.J., Last, K.S., Wilson, B., Wilson, B., Miller, R.G., Hutchison, Z.L., Macleod, A.K., Burrows, M.T., Cook, E., Last, K.S., 2013. Marine renewable energy development: assessing the Benthic Footprint at multiple scales. Front. Ecol. Environ. 11, 433-440.

Mitchell, P.I., Newton, S.F., Ratcliffe, N., Dunn, T.E., 2004. Seabird populations of Britain and Ireland: results of the Seabird 2000 census (1998-2002). T and A.D. Poyser, London.

MMO, 2019. Improved understanding of underwater collision risks of marine renewable energy devices for birds while diving. A Rep. Prod. by Br. Trust Ornithol. Mar. Manag. Organ. behalf Mar. Biodivers. Impacts Evid. Gr.

Neill, S.P., Hashemi, M.R., Lewis, M.J., 2016. Tidal energy leasing and tidal phasing. Renew. Energy 85, 580-587. https://doi.org/10.1016/j.renene.2015.07.016

Neill, S.P., Litt, E.J., Couch, S.J., Davies, A.G., 2009. The impact of tidal stream turbines on large-scale sediment dynamics. Renew. Energy 34, 2803-2812.

https://doi.org/10.1016/j.renene.2009.06.015

Neill, S.P., Vögler, A., Goward-Brown, A.J., Baston, S., Lewis, M.J., Gillibrand, P.A., Waldman, S., Woolf, D.K., 2017. The wave and tidal resource of Scotland. Renew. Energy 114, 3-17. https://doi.org/10.1016/j.renene.2017.03.027 
Nol, E., Gaskin, D.E., 1987. Distribution and movements of Black Guillemots ( Cepphus grylle ) in coastal waters of the southwestern Bay of Fundy, Canada. Can. J. Zool. 65, 2682-2689. https://doi.org/10.1139/z87-407

O’Doherty, T., Mason-Jones, A., O’Doherty, D.M., Evans, P.S., Wooldridge, C.F., Fryett, I., 2010. Considerations of a horizontal axis tidal turbine. Proc. Inst. Civ. Eng. Energy 163, 119-130. https://doi.org/10.1680/ener.2010.163.3.119

O Rourke, F., Boyle, F., Reynolds, A., 2010. Tidal energy update 2009. Appl. Energy 87, 398-409. https://doi.org/10.1016/J.APENERGY.2009.08.014

Ocean Energy Systems, 2019. OES | Ocean energy in the World [WWW Document]. URL https://www.ocean-energy-systems.org/ocean-energy-in-the-world/ (accessed 3.28.19). Ocean Energy Systems, 2016. Annual Report 2016.

Orians, G.H., Pearson, N.E., 1979. On the theory of central place foraging, in: Horn, D.J. (Ed.), Analysis of Ecological Systems. Ohio State University Press, Columbus, Ohio, pp. 155-177.

Pelc, R., Fujita, R.M., 2002. Renewable energy from the ocean. Mar. Policy 26, 471-479. https://doi.org/10.1016/S0308-597X(02)00045-3

Phillips, E.M., Horne, J.K., Zamon, J.E., Felis, J.J., Adams, J., 2019. Does perspective matter? A case study comparing Eulerian and Lagrangian estimates of common murre (Uria aalge) distributions. Ecol. Evol. 9, 4805-4819. https://doi.org/10.1002/ece3.5083

Philpott, E., 2013. Examining potential effects of marine renewable energy developments on top predators. University of Aberdeen.

Pichegru, L., Nyengera, R., Mcinnes, A.M., Pistorius, P., 2017. Avoidance of seismic survey activities by penguins. Sci. Rep. 7. https://doi.org/10.1038/s41598-017-16569-x

Polagye, B., Copping, A., Suryan, R., Kramer, S., Brown-Saracino, J., 2014. Instrumentation for Monitoring around Marine Renewable Energy Converters: Workshop Final Report. Seattle, WA. Raya Rey, A., Bost, C.-A., Schiavini, A., Pütz, K., 2010. Foraging movements of Magellanic Penguins Spheniscus magellanicus in the Beagle Channel, Argentina, related to tide and tidal currents. J. 
Ornithol. 151, 933-943. https://doi.org/10.1007/s10336-010-0531-y

Resch, G., Held, A., Faber, T., Panzer, C., Toro, F., Haas, R., 2008. Potentials and prospects for renewable energies at global scale. Energy Policy 36, 4048-4056.

Robbins, A., 2012. Analysis of Bird and Marine Mammal Data for Fall of Warness Tidal Test Site, Orkney, Orkney. Scottish Natural Heritage Commissioned Report.

Robbins, A.M.C., 2017. Seabird ecology in high-energy environments: approaches to assessing impacts of marine renewables. University of Glasgow.

Robbins, A.M.C., Furness, R.W., Thaxter, C.B., Daunt, F.H., Cook, A.S.C.P., Masden, E.A., 2014. A review of marine bird diving behaviour : assessing underwater collision risk with tidal turbines. Proc. 2nd Int. Conf. Environ. Interact. Mar. Renew. Energy Technol. (EIMR2014), 28 April - 02 May 2014, Stornoway, Isle Lewis, Outer Hebrides, Scotl. 2-3.

Robins, P.E., Neill, S.P., Lewis, M.J., 2014. Impact of tidal-stream arrays in relation to the natural variability of sedimentary processes. Renew. Energy 72, 311-321.

https://doi.org/10.1016/j.renene.2014.07.037

Roche, R.C., Walker-Springett, K., Robins, P.E., Jones, J., Veneruso, G., Whitton, T.A., Piano, M., Ward, S.L., Duce, C.E., Waggitt, J.J., Walker-Springett, G.R., Neill, S.P., Lewis, M.J., King, J.W., 2016. Research priorities for assessing potential impacts of emerging marine renewable energy technologies: Insights from developments in Wales (UK). Renew. Energy 99, 1327-1341. https://doi.org/10.1016/j.renene.2016.08.035

Rodger, C.C., 2014. Diving seabirds in a high energy tidal environment: Distribution, behaviour and predicted interaction with tidal stream turbines at Bluemull Sound, Shetland MSc Dissertation by Christopher Craig Rodger.

Ropert-Coudert, Y., Grémillet, D., Kato, A., 2006. Swim speeds of free-ranging great cormorants. Mar. Biol. 149, 415-422. https://doi.org/10.1007/s00227-005-0242-8 Royal Haskoning, 2011. SeaGen Environmental Monitoring Programme Final Report. Edinburgh, UK. RPS, 2011. Assessment of Risk to Diving Birds from Underwater Marine Renewable Devices in Welsh 
Waters.

Sæther, B.-E., Øyvind, B., 2000. Avian life history variation and contribution of demographic traits to the population growth rate. Ecology 81, 642-653.

Savidge, G., Ainsworth, D., Bearhop, S., Christen, N., Elsaesser, B., Fortune, F., Inger, R., Kennedy, R., McRobert, A., Plummer, K.E., Pritchard, D.W., Sparling, C.E., Whittaker, T.J.T., 2014. Strangford Lough and the SeaGen Tidal Turbine, in: Shields, M.A., Payne, A.I.L. (Eds.), Marine Renewable Energy Technology and Environmental Interactions. Springer, Dordrecht, pp. 153-172. https://doi.org/10.1007/978-94-017-8002-5_12

Scott, B.E., Langton, R., Philpott, E., Waggitt, J.J., 2014. Seabirds and marine renewables: are we asking the right questions?, in: Marine Renewable Energy Technology and Environmental Interactions. pp. 81-92. https://doi.org/10.1007/978-94-017-8002-5

Scottish Natural Heritage, 2016. Assessing collision risk between underwater turbines and marine wildlife. SNH gudance note.

ScottishPower Renewables, 2010. Sound of Islay Demonstration Tidal Array Environmental Statement. Glasgow.

SeaGeneration Kyle Rhea Ltd., 2014. The Kyle Rhea Tidal Stream Array: Volume II - Environmental Statement.

Searle, K.R., Mobbs, D.C., Butler, A., Furness, R.W., Trinder, M.N., Daunt, F., 2018. Finding out the Fate of Displaced Birds. Scottish Mar. Freshw. Sci. 9. https://doi.org/10.7489/12118-1

Segura, E., Morales, R., Somolinos, J.A., 2018. A strategic analysis of tidal current energy conversion systems in the European Union. Appl. Energy 212, 527-551.

https://doi.org/10.1016/j.apenergy.2017.12.045

Shields, M.A., Dillon, L.J., Woolf, D.K., Ford, A.T., 2009. Strategic priorities for assessing ecological impacts of marine renewable energy devices in the Pentland Firth (Scotland, UK). Mar. Policy 33, 635-642. https://doi.org/10.1016/J.MARPOL.2008.12.013

Shields, M.A., Payne, A.I.L., 2014. Marine renewable energy technology and environmental 
interactions. Springer, Dordrecht.

Shields, M.A., Woolf, D.K., Grist, E.P.M., Kerr, S.A., Jackson, A.C., Harris, R.E., Bell, M.C., Beharie, R., Want, A., Osalusi, E., Gibb, S.W., Side, J., 2011. Marine renewable energy: The ecological implications of altering the hydrodynamics of the marine environment. Ocean Coast. Manag. 54, 2-9. https://doi.org/10.1016/J.OCECOAMAN.2010.10.036

Stallard, T., Collings, R., Feng, T., Whelan, J., 2013. Interactions between tidal turbine wakes: Experimental study of a group of three-bladed rotors. Philos. Trans. R. Soc. A Math. Phys. Eng. Sci. 371. https://doi.org/10.1098/rsta.2012.0159

Taormina, B., Bald, J., Want, A., Thouzeau, G., Lejart, M., Desroy, N., Carlier, A., 2018. A review of potential impacts of submarine power cables on the marine environment: Knowledge gaps, recommendations and future directions. Renew. Sustain. Energy Rev. 96, 380-391. https://doi.org/10.1016/j.rser.2018.07.026

Taylor, P., Walker, J., 2019. Using radar data to evaluate seabird abundance and habitat use at the Funsy Ocean Research Centre for Energy site near Parrboro, NS [WWW Document]. Offshore Energy Res. Assoc. URL

https://www2.gov.scot/Topics/marine/marineenergy/mre/research/ornithology (accessed 1.25.19).

Trevail, A.M., Green, J.A., Sharples, J., Polton, J.A., Miller, P.I., Daunt, F., Owen, E., Bolton, M., Colhoun, K., Newton, S., Robertson, G., Patrick, S.C., 2019. Environmental heterogeneity decreases reproductive success via effects on foraging behaviour. Proc. R. Soc. B Biol. Sci. 286, 20190795. https://doi.org/10.1098/rspb.2019.0795

Urmy, S.S., Warren, J.D., 2018. Foraging hotspots of common and roseate terns: The influence of tidal currents, bathymetry, and prey density. Mar. Ecol. Prog. Ser. 590, 227-245. https://doi.org/10.3354/meps12451

Van Parijs, S.M., Hastie, G.D., Thompson, P.M., 1999. Geographical variation in temporal and spatial vocalization patterns of male harbour seals in the mating season. Anim. Behav. 58, 1231-1239. 
W Langston, R.H., 2010. Offshore wind farms and birds: Round 3 zones, extensions to Round 1 \&amp; Round 2 sites \&amp; Scottish Territorial Waters.

Wade, H.M., 2015. Investigating the potential effects of marine renewable energy developments on seabirds. University of Aberdeen.

Wade, H.M., Masden, E.A., Jackson, A.C., Furness, R.W., 2016. Incorporating data uncertainty when estimating potential vulnerability of Scottish seabirds to marine renewable energy developments. Mar. Policy 70, 108-113. https://doi.org/10.1016/j.marpol.2016.04.045

Wade, H.M., Masden, E.A., Jackson, A.C., Thaxter, C.B., Burton, N.H.K., Bouten, W., Furness, R.W., 2014. Great skua (Stercorarius skua) movements at sea in relation to marine renewable energy developments. Mar. Environ. Res. 101, 69-80.

https://doi.org/10.1016/j.marenvres.2014.09.003

Waggitt, J.J., Bell, P.S., Scott, B.E., 2014. An evaluation of the use of shore-based surveys for estimating spatial overlap between deep-diving seabirds and tidal stream turbines. Int. J. Mar. Energy 8, 36-49. https://doi.org/10.1016/j.ijome.2014.10.004

Waggitt, J.J., Cazenave, P.W., Torres, R., Williamson, B.J., Scott, B.E., 2016a. Predictable hydrodynamic conditions explain temporal variations in the density of benthic foraging seabirds in a tidal stream environment. ICES J. Mar. Sci. 73, 2677-2686. https://doi.org/10.1093/icesjms/fsw100

Waggitt, J.J., Cazenave, P.W., Torres, R., Williamson, B.J., Scott, B.E., 2016b. Quantifying pursuitdiving seabirds' associations with fine-scale physical features in tidal stream environments. J. Appl. Ecol. 53, 1653-1666. https://doi.org/10.1111/1365-2664.12646

Waggitt, J.J., Robbins, A.M.C., Wade, H.M., Masden, E.A., Furness, R.W., Jackson, A.C., Scott, B.E., 2017. Comparative studies reveal variability in the use of tidal stream environments by seabirds. Mar. Policy 81, 143-152. https://doi.org/10.1016/j.marpol.2017.03.023 Waggitt, J.J., Scott, B.E., 2014. Using a spatial overlap approach to estimate the risk of collisions between deep diving seabirds and tidal stream turbines: A review of potential methods and 
approaches. Mar. Policy 44, 90-97. https://doi.org/10.1016/j.marpol.2013.07.007

Walker, J., Taylor, P., 2018. Using radar data to evaluate seabird abundance and habitat use at the Fundy Ocean Research Centre for Energy site near Parrsboro, NS. Parrsboro.

Wanless, S., Frederiksen, M., Daunt, F., Scott, B.E., Harris, M.P., 2007. Black-legged kittiwakes as indicators of environmental change in the North Sea: Evidence from long-term studies. Prog. Oceanogr. 72, 30-38. https://doi.org/10.1016/j.pocean.2006.07.007

Warwick-Evans, V.C., Atkinson, P.W., Robinson, L.A., Green, J.A., 2016. Predictive Modelling to Identify Near-Shore, Fine-Scale Seabird Distributions during the Breeding Season. PLoS One 11, e0150592. https://doi.org/10.1371/journal.pone.0150592

Watanuki, Y., Suryan, R.M., Sasaki, H., Yamamoto, T., Hazen, E.L., Renner, M., Santora, J.A., O’Hara, P.D., Sydeman, W.J., 2016. Spatial Ecology of Marine Top Predators in the North Pacific: Tools for Integrating across Datasets and Identifying High Use Areas, PICES Scientific Report.

Watanuki, Y., Wanless, S., Harris, M., Lovvorn, J.R., Miyazaki, M., Tanaka, H., Sato, K., 2006. Swim speeds and stroke patterns in wing-propelled divers: a comparison among alcids and a penguin. J. Exp. Biol. 209, 1217-1230. https://doi.org/10.1242/jeb.02128

Weimerskirch, H., 2007. Are seabirds foraging for unpredictable resources? Deep Sea Res. Part II Top. Stud. Oceanogr. 54, 211-223. https://doi.org/10.1016/J.DSR2.2006.11.013

Weinstein, B.G., 2018. A computer vision for animal ecology. J. Anim. Ecol. 87, 533-545. https://doi.org/10.1111/1365-2656.12780

White, C.R., Day, N., Butler, P.J., Martin, G.R., 2007. Vision and Foraging in Cormorants: More like Herons than Hawks? PLoS One. https://doi.org/10.1371/journal.pone.0000639 Whitton, T.A., Jackson, S.E., Hiddink, J.G., Scoulding, B., Bowers, D., Powell, B., D’Urban Jackson, T., Giménez, L., Davies, A.G., 2020. Data from: Vertical migrations of fish schools determine overlap with a mobile tidal stream marine renewable energy device 1-13. https://doi.org/10.6084/m9.figshare.11671740 Williamson, B., Fraser, S., Mcilvenny, J., Couto, A., Chapman, J., Wade, H., Martin, J., Wilson, J., 
Evans, T., Hunter, D., Fenn, S., Culloch, R., Tait, A., Chimienti, M., Edwards, E., Williamson, L., Davies, I., Scott, B., 2018. Multi-platform studies of the MeyGen tidal energy site-using UAVs to measure animal distributions and hydrodynamic features, in: MASTS: Annual Science Meeting.

Williamson, B., Fraser, S., Williamson, L., Nikora, V., Scott, B., 2019. Predictable changes in fish school characteristics due to a tidal turbine support structure. Renew. Energy 141, 1092-1102. https://doi.org/10.1016/j.renene.2019.04.065

Williamson, B.J., Fraser, S., Blondel, P., Bell, P.S., Waggitt, J.J., Scott, B.E., 2017. Multisensor Acoustic Tracking of Fish and Seabird Behavior Around Tidal Turbine Structures in Scotland. IEEE J.

Ocean. Eng. 42, 948-965. https://doi.org/10.1109/JOE.2016.2637179

Wilson, B.., Batty, R.S.., Daunt, F.., Carter, C., 2006. Collision risks between marine renewable energy devices and mammals, fish, and diving birds. Rep. to Scottish Exec.

Wilson, B., Batty, R.S., Daunt, F., Carter, C., 2007. Collision risks between marine renewable energy devices and mammals, fish and diving birds. Oban.

Wolanski, Eric; Hamner, W.M., 1988. Topographically Controlled Fronts in the Ocean and Their Biological Influence. Science (80-. ). 241, 177-181.

Yamamoto, T., Watanuki, Y., Hazen, E.L., Nishizawa, B., Sasaki, H., Takahashi, A., 2015. Statistical integration of tracking and vessel survey data to incorporate life history differences in habitat models. Ecol. Appl. 25, 2394-2406. https://doi.org/10.1890/15-0142.1

Zamon, J.E., 2003. Mixed species aggregations feeding upon herring and sandlance schools in a nearshore archipelago depend on flooding tidal currents. Mar. Ecol. Prog. Ser. 261, 243-255. https://doi.org/10.3354/meps261243

Zamon, J.E., 2001. Seal predation on salmon and forage fish schools as a function of tidal currents in the San Juan Islands, Washington, USA. Fish. Oceanogr. 10, 353-366. https://doi.org/10.1046/j.1365-2419.2001.00180.x

Zhou, Z., Benbouzid, M., Charpentier, J.-F., Scuiller, F., Tang, T., 2017. Developments in large marine current turbine technologies - A review. Renew. Sustain. Energy Rev. 71, 852-858. 
491 